\title{
Evaluación de las propiedades eléctricas de morteros de cemento con puzolanas
}

\section{Evaluation of electric properties of cement mortars containing pozzolans}

\author{
J. M. Cruz $z^{(*)}$, J. Payá(**), L. F. Lalinde(**), $\underline{\text { I. C. Fita }}(*)$
}

Recepción/Received: 15-VII-09 Aceptación/Accepted: 29-III-10

Publicado online/Online publishing: 15-IV-10

\section{RESUMEN}

En este trabajo se analiza la microestructura de morteros de cemento Portland, mediante medidas de impedancia eléctrica. Se comparan morteros de cemento sin y con dos sustituciones puzolánicas: residuo de catalizador de craqueo catalítico (FCC) y metacaolín (MK). Se describe el método de medida y se desarrolla el modelo de análisis de los espectros de impedancia eléctrica. Se definen tres parámetros eléctricos: resistividad eléctrica, exponente capacitivo y factor capacitivo. Se observa un aumento importante de la resistividad de los morteros con puzolana a partir de los 7 días de curado, sobre todo en morteros con MK. Este aumento está correlacionado con la fijación de cal de las puzolanas. Las propiedades capacitivas son diferentes a edad temprana, pero se igualan a los 148 días. Los resultados eléctricos y mineralógicos muestran que la evolución microestructural comienza antes en los morteros con MK que con FCC y que la microestructura final es diferente.

Palabras clave: adición activa, análisis térmico, hidratación, hidróxido cálcico, impedancia eléctrica.

\section{SUMMARY}

In this paper the evolution of the microstructure of Portland cement mortar is analyzed, by using electrical impedance measurements. Cement mortars are compared without and with two pozzolanic substitutions: spent fluid catalytic cracking catalyst (FCC) and metakaolin (MK). The measurement method is described and the model for analyzing the electrical impedance spectra is developed. Three electrical parameters are defined: electrical resistivity, capacitance exponent, and capacitive factor. The results show a significant increase in resistivity of the mortars with pozzolans after 7 days of curing, especially in mortars with MK. This increase is correlated with lime-fixing by the pozzolans. The capacitive properties evolve differently at early age, but reach the same values after 148 days. The electrical and mineralogical data show that the evolution of the microstructure in the mortar with MK starts before it does in the mortars with FCC and that the final microstructure becomes different.

Keywords: active addition, thermal analysis, hydration, calcium hydroxide, electrical impedance.

(*) Universidad Politécnica de Valencia (Valencia, España).

(**) Instituto de Ciencia y Tecnología del Hormigón (ICITECH) (Valencia, España). 


\section{INTRODUCCIÓN}

Los productos derivados del cemento Portland (pasta de cemento, mortero y hormigón) son materiales porosos con dos fases: fase sólida y fase porosa. La fase sólida consta de partículas con diferente composición y tamaño: i) partículas de cemento parcialmente hidratadas o no-hidratadas, de algunas micras, ii) arena (en mortero), de algunos milímetros, y iii) grava (en hormigón) de hasta algunos centímetros.

La fase porosa contiene poros de tamaño muy variado, algunos de ellos aislados entre sí y no conectados con el exterior (porosidad cerrada o bloqueada). El resto de poros están interconectados entre sí formando canales de conexión con el exterior (porosidad conectada o abierta). La fase sólida y los productos de hidratación constituyen la interfase poro-solución. Los poros se clasifican según el tamaño: i) poros de gel o productos hidratados, de tamaño inferior a $10 \mathrm{~nm}$ (interconectados entre 1 y $10 \mathrm{~nm}$ ), ii) poros capilares, entre $10 \mathrm{~nm}$ y 1 micra, que contribuyen a los procesos de transporte, y iii) poros mayores de 1 micra, asociados al contenido en aire atrapado. La tortuosidad de la porosidad abierta, el tamaño medio del poro bloqueado y su varianza son propiedades que cambian durante la hidratación $(1,2)$.

Las propiedades eléctricas en baja y media frecuencia (hasta el orden del $\mathrm{MHz}$ ) reflejan el movimiento de iones en la solución de los poros y, por tanto, son función de la geometría de la porosidad. La resistividad eléctrica en corriente continua de un material poroso es proporcional a la movilidad de los iones en la porosidad conectada. El factor de formación y la difusión de los iones en el medio poroso se pueden calcular a partir de la resistividad del material y la resistividad de la solución del poro (3). La difusión del ión cloruro es responsable de la degradación de la estructura metálica del hormigón armado, la cual tiene importantes consecuencias económicas (4). La capacidad eléctrica del material está relacionada con la geometría de la porosidad bloqueada (5) y el carácter fractal del poro bloqueado (6).

Las mediciones eléctricas tienen grandes ventajas como: ser no destructivas y realizarse rápida y automáticamente en cualquier momento de la hidratación. Además pueden servir para caracterizar el grado de hidratación de un mortero de cemento Pórtland complementando las mediciones de las propiedades mecánicas a edad temprana.

El uso de puzolanas en la preparación de morteros y hormigones es una práctica habitual porque mejoran las propiedades mecánicas y aumentan su durabilidad en ambientes con agentes agresivos. Estas mejoras se atribuyen a dos procesos: i) la formación de productos hidratados adicionales debido a la reacción de la puzolana con

\section{INTRODUCTION}

Products derived from Portland cement (cement paste, mortar and concrete) are porous materials with two phases: solid phase and pore phase. The solid phase consists of particles with different composition and size: i) partially hydrated cement particles or non-hydrated, a few microns, ii) sand (in mortar), a few millimeters, and iii) gravel (concrete) up few centimeters.

The porous phase contains pores of varied sizes, some of them isolated from each other and not connected with the outside (closed or blocked porosity). The remaining pores are interconnected, forming channels connecting with the outside (open or connected porosity). The solid phase and the hydration products are the pore-solution interface. The pores are classified according to size: i) pores of gel or hydrated products, smaller than $10 \mathrm{~nm}$ (interconnected between 1 and $10 \mathrm{~nm}$ ), ii) capillary pores between $10 \mathrm{~nm}$ and 1 micron, which contribute to the processes of transport, and iii) pores larger than 1 micron, associated with trapped air content. The tortuosity of open porosity, the average size of the blocked pore and its variance are changing properties during hydration $(1,2)$.

The electrical properties at low and medium frequency (up to the order of $\mathrm{MHz}$ ) reflect the movement of ions in the pore solution and therefore are a function of the geometry of the porosity. The dc electrical resistivity of a porous material is proportional to the mobility of ions in the connected porosity. The formation factor and the diffusion of ions in the porous medium can be calculated from the resistivity of the material and the resistivity of the pore solution (3). The diffusion of chloride ion is responsible for degradation of the metallic structure of reinforced concrete, which has significant economic consequences (4). The electrical capacitance of the material is related to the geometry of the blocked porosity (5) and the fractal nature of the blocked pore (6).

The electrical measurements have great advantages such as being non-destructive and performed quickly and automatically at any time of hydration. They can also serve to characterize the degree of hydration of Portland cement mortar complementing measurements of mechanical properties at early age.

The use of pozzolans in the preparation of mortar and concrete is a common practice because they improve the mechanical properties and increase their durability in environments with aggressive agents. These improvements are attributed to two processes: i) the formation of additional hydrated products due to 
del hidróxido cálcico derivado de la hidratación del cemento y ii) la reducción de la permeabilidad por el efecto del llenado de los poros con los productos formados en la reacción puzolánica (7). Estos procesos deberían reflejarse en las propiedades eléctricas.

Las puzolanas artificiales pueden ser productos manufacturados a partir de materias primas específicas, como el caso del metacaolin (MK), o residuos procedentes de determinados procesos industriales como el fluido catalizador de craqueo (FCC).

El MK es un producto de síntesis, manufacturado mediante la calcinación del caolín, de gran finura (hasta 1-2 $\mu \mathrm{m})$ y con elevada actividad puzolánica. Se ha demostrado en un gran número de estudios que el MK proporciona mejoras significativas tanto en la resistencia mecánica como en la durabilidad de los morteros $(8,9)$.

El FCC es un residuo procedente de la industria petroquímica constituido por partículas con una morfología variada (esférica o esferoidal) con una elevada porosidad y una gran superficie específica $(10,11)$. Se ha comprobado que FCC tiene gran actividad puzolánica a edad temprana, siendo ligeramente superior que el humo de sílice y significativamente mayor que la ceniza volante (12-14). También se ha comprobado que morteros y hormigones alcanzan los mayores valores de resistencia a compresión cuando la sustitución de cemento por FCC es del orden del 10-20\% (10). El elevado consumo de hidróxido cálcico derivado de la alta actividad puzolánica del FCC a edad temprana, produce un adelanto en el inicio del fraguado, a la vez que se observa un incremento en la formación de etringita inicial y una aceleración en la hidratación de los silicatos cálcicos (14).

Las pastas y morteros con FCC presentan elevados porcentajes de cal fijada, similares o superiores a otras puzolanas comúnmente usadas. Comparado con MK, su comportamiento mejora a edad temprana y el proceso de hidratación se acelera sin un aumento significativo del calor total de hidratación (15). Además, su elevada actividad produce notables mejoras en las propiedades mecánicas de los morteros y lo convierte en un posible sustituto de cemento o de árido (16).

El objetivo de este artículo es relacionar los efectos de las reacciones puzolánicas con las propiedades eléctricas de los morteros, y así conocer mejor la evolución de la microestructura mediante técnicas no destructivas. Se evalúan morteros de cemento Pórtland (CONTROL) y morteros con sustitución parcial de cemento ( $15 \%$ en peso). Las puzolanas utilizadas son: catalizador de craqueo catalítico (FCC) y metacaolín (MK). Se mide la impedancia eléctrica en el rango de $20 \mathrm{~Hz}$ y $1 \mathrm{MHz}$ y se obtiene la impedancia intrínseca por el método de área reaction of pozzolan with calcium hydroxide resulting from hydration of cement, and ii) reduction of permeability by the effect of filling the pores with the products formed in the pozzolanic reaction (7). These processes should be reflected in the electrical properties.

The artificial pozzolans can be manufactured from specific materials, like the case of metakaolin (MK), or wastes from certain industrial processes such as spent fluid catalytic cracking catalyst (FCC).

MK is a synthetic product, manufactured by calcination of kaolin, very fine (up to 1-2 $\mu \mathrm{m}$ ) and with high pozzolanic activity. It has been demonstrated in a large number of studies that $M K$ provides significant improvements in both mechanical strength and the durability of the mortars $(8,9)$.

FCC is a waste from the petrochemical industry made up of particles with a varied morphology (spherical or spheroidal) with high porosity and large specific surface $(10,11)$. It has been shown that FCC has high pozzolanic activity at an early age, being slightly higher than the silica fume and significantly higher than fly ash (12-14). It was also found that mortars and concretes reached the highest values of compressive strength when the replacement of cement by FCC is the order of $10-20 \%$ (10). The high consumption of calcium hydroxide resulting from the high pozzolanic activity of FCC at early age, produces an advance in the setting point, while there is an increase in initial ettringite formation and an acceleration in the hydration of calcium silicates (14).

FCC pastes and mortars have high percentages of fixed lime, similar or superior to other commonly used pozzolans. Compared with $M K$, his behaviour improves at early age and the hydration process is accelerated without a significant increase in total heat of hydration (15). Moreover, their high activity can significantly improve the mechanical properties of mortars and can be used as a substitute for cement or aggregate (16).

The aim of this paper is to relate the effects of pozzolanic reactions with the electrical properties of the mortars, and thus better understand the evolution of microstructure through non-destructive techniques. Portland cement mortars (CONTROL) and mortars with partial replacement of cement are evaluated (15\% by weight). The used pozzolans are: spent fluid catalytic craking catalyst (FCC) and metakaolin (MK). Electrical impedance is measured in the range of $20 \mathrm{~Hz}$ and $1 \mathrm{MHz}$ and the intrinsic impedance is obtained by the method of 
variable. Se deducen tres parámetros eléctricos: resistividad, exponente capacitivo y factor capacitivo, y su evolución se analiza en el periodo de curado (1-148 días). Los resultados de las mediciones eléctricas son relacionados con los obtenidos en los ensayos mecánicos y de caracterización mineralógica de la matriz cementante.

\section{MATERIALES Y PROCEDIMIENTOS}

\subsection{Elaboración de especímenes}

Se han fabricado tres tipos de mortero con cemento Pórtland tipo CEM I 52.5R, de acuerdo con el procedimiento descrito en la norma UNE-EN 196-1. La relación árido/cemento es $3 / 1$ y la relación agua/cemento es 0,5. El mortero de referencia CONTROL solamente contiene cemento Portland como conglomerante, en los otros dos FCC y MK sustituyen $15 \%$ de cemento (en peso), respectivamente. Las propiedades de las dos puzolanas silico-aluminosas se resumen en la Tabla 1. Los morteros frescos se han vertido en moldes cilíndricos de PVC, se han conservado en atmósfera saturada durante las primeras 24 horas, después se han extraído del molde y sumergido en solución saturada de cal a $20^{\circ} \mathrm{C}$. Se han elaborado cuatro muestras para cada mortero, en forma de cilindro hueco, de radio exterior $\mathrm{a}=5 \mathrm{~cm}$, de radio interior $b=1 \mathrm{~cm}$ y de altura $h=6 \mathrm{~cm}$. variable area. Three electrical parameters are derived: resistivity, capacitive exponent and capacitive factor, and their evolution is discussed in curing period (1-148 days). The results of electrical measurements are compared to those obtained in mechanical tests and mineralogical characterization of the cementing matrix.

\section{MATERIALS AND PROCEDURES}

\subsection{Preparation of specimens}

Three types of mortar have been made with Portland cement type CEM I 52.5R, according to the procedure described in the UNE-EN 196-1. The relationship arid / cement is $3 / 1$ and the water/cement ratio is 0.5 . The reference mortar CONTROL contains only Portland cement as binder, in the other two FCC and MK replaced $15 \%$ of cement (by weight), respectively. The properties of the two silico-aluminous pozzolans are summarized in Table 1. The fresh mortars were poured into cylindrical PVC moulds, were preserved in saturated atmosphere for 24 hours, then were extracted from the mould and immersed in saturated lime solution at $20^{\circ} \mathrm{C}$. Four samples have been prepared for each mortar, in the form of hollow cylinder of outer radius $a=5 \mathrm{~cm}$, inner radius $b=1 \mathrm{~cm}$ and height $h=6 \mathrm{~cm}$.

Tabla 1 / Table 1

Composición química y datos granulométricos de FCC y MK (* Pérdida al fuego). Chemical and granulometric data for FCC and MK (* Loss on ignition).

\begin{tabular}{|c|c|c|c|c|c|c|c|c|c|c|}
\hline$\%$ & $\mathrm{SiO}_{2}$ & $\mathrm{Al}_{2} \mathrm{O}_{3}$ & $\mathrm{Fe}_{2} \mathrm{O}_{3}$ & $\mathrm{CaO}$ & MgO & $\mathrm{SO}_{3}$ & $\mathrm{~K}_{2} \mathrm{O}$ & $\begin{array}{l}\mathrm{Na}_{2} \mathrm{O} \text { I } \\
{ }^{2} \mathrm{LOI}\end{array}$ & ${ }^{*} \mathrm{PF}$ & $\begin{array}{c}\emptyset_{\text {medio }}(\mu \mathrm{m}) / \\
\emptyset_{\text {mean }}(\mu \mathrm{m})\end{array}$ \\
\hline FCC & 46.04 & 47.47 & 0.58 & 0.11 & 0.17 & 0.02 & 0.02 & 0.3 & 0.49 & 19.73 \\
\hline MK & 52.1 & 41.0 & 4.32 & 0.07 & 0.19 & N.D & 0.63 & 0.26 & 0.6 & 5.84 \\
\hline
\end{tabular}

Se han realizado ensayos eléctricos a las edades de 1,3 , 7, 14 y 148 días, ensayos mecánicos a las edades de 3, 7, 14 y 148 días, y ensayos mineralógicos a las edades de 7 , 14 y 148 días. El número de probetas de mortero ha ido disminuyendo conforme se han realizado los ensayos destructivos.

\subsection{Procedimiento de medidas eléctricas macroscópicas (impedancia eléctrica)}

El método más frecuente para obtener las propiedades eléctricas macroscópicas consiste en medir la impedancia eléctrica en función de la frecuencia. Se trata de aplicar una corriente eléctrica de frecuencia variable mediante dos electrodos metálicos y medir su diferencia de potencial. La intensidad ha de ser pequeña para minimizar el efecto electroquímico (17-20). Otro método, aplicado recientemente, no utiliza electrodos y la corriente eléctrica es inducida mediante un campo magnético variable (21).
Electrical tests have been conducted at ages 1, 3, 7, 14 and 148 days, mechanical tests at ages 3, 7, 14 and 148 days, and mineralogical tests at ages 7, 14 and 148 days. The number of mortar specimens was reduced each time it was a destructive test.

\subsection{Procedure for macroscopic electrical measurements (electrical impedance)}

The most common method to obtain the macroscopic electrical properties is to measure the electrical impedance versus frequency. It involves applying a variable frequency electric current through two metallic electrodes and measuring its potential difference. The intensity should be small to minimize the electrochemical effect (17-20). Another method, recently implemented, does not use electrodes and the electric current is induced by a varying magnetic field (21). 
Independientemente del método utilizado, para obtener la impedancia intrínseca del mortero, es necesario evaluar y corregir los efectos parásitos: borde de la muestra, electrodos metálicos (si los hay), cables de conexión y equipo de medida (22).

Hemos medido la impedancia eléctrica mediante el analizador de impedancias Solartron SI 1260 aplicando una intensidad constante de $100 \mu \mathrm{A}$. Cada medición consiste en un barrido de 59 frecuencias desde $20 \mathrm{~Hz}$ hasta $1 \mathrm{MHz}$ equidistantes en escala logarítmica. La celda de medida (Figura 1) está compuesta por dos electrodos cilíndricos concéntricos de acero inoxidable, de $3 \mathrm{~mm}$ y $55 \mathrm{~mm}$ de radios, respectivamente, y $60 \mathrm{~mm}$ de altura. La solución saturada de $\mathrm{Ca}(\mathrm{OH})_{2}$, en la que el mortero se está hidratando $(1 \mathrm{~S} / \mathrm{m}$ de conductividad) se utilizó como elemento de contacto entre electrodos y muestra. Las medidas se han tomado a $20^{\circ} \mathrm{C}$.
Regardless of the method used, to obtain the intrinsic impedance of the mortar, it is necessary to evaluate and correct the parasitic effects: sample edge, metallic electrodes (if any), connecting cables and measuring equipment (22).

We have measured the electrical impedance using an impedance analyzer Solartron SI 1260 applying a constant current of $100 \mu \mathrm{A}$. Each measurement consists of a sweep of 59 frequencies from $20 \mathrm{~Hz}$ to $1 \mathrm{MHz}$ equidistant in logarithmic scale. The measuring cell (Figure 1) consists of two concentric cylindrical electrodes of stainless steel, $3 \mathrm{~mm}$ and $55 \mathrm{~mm}$ radii, respectively, and $60 \mathrm{~mm}$ high. The saturated solution of $\mathrm{Ca}(\mathrm{OH})_{2}$, in which the mortar is hydrating $(1 \mathrm{~S} / \mathrm{m}$ conductivity) was used as a contact between electrodes and sample. Measurements were taken at $20^{\circ} \mathrm{C}$.

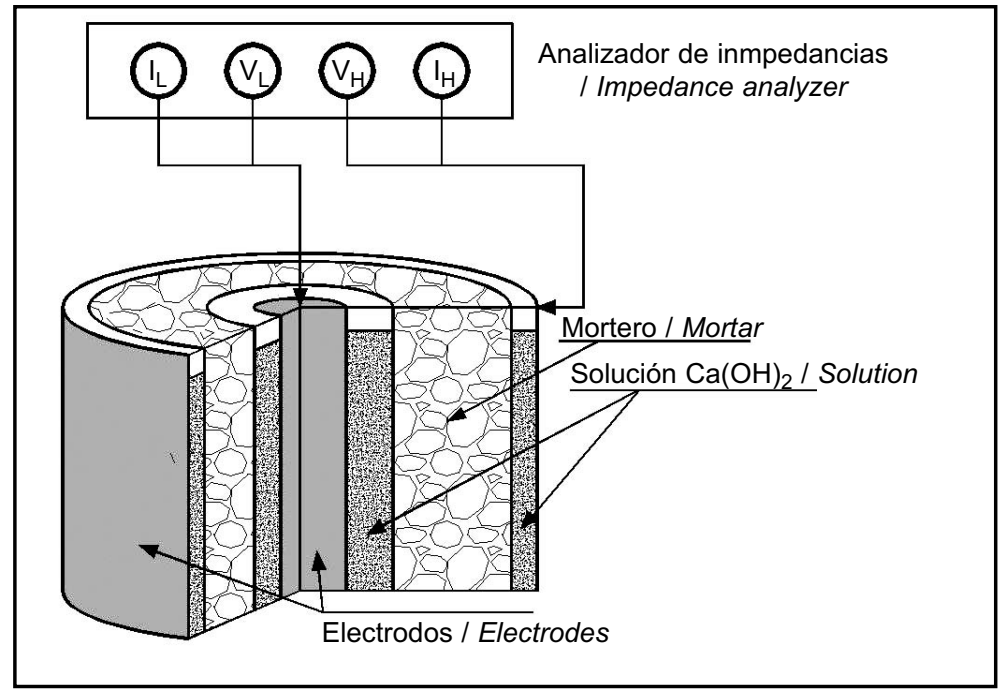

Figura 1. Esquema de la celda eléctrica de medida. $\mathrm{I}_{\mathrm{L}} \mathrm{I}_{\mathrm{H}}$ son los bornes de entrada y salida de la corriente.

$V_{H}$ y $V_{L}$ son los bornes de medida de la diferencia de potencial.

Figure 1. Outline of electrical cell of measurement. $I_{L^{\prime}} I_{H}$ are the imput and output of current.

$V_{H}$ y $V_{L}$ are the measurement points of potential difference.

Para eliminar los efectos ajenos al mortero, se ha medido la impedancia ( $Z$ ) frente a la altura, llenando la celda con diferentes alturas $\left(h_{i}\right)$ de solución. Se ha medido la impedancia con 6 alturas y se han descartado las dos extremas. Se ha calculado la admitancia $(Y)$ como el inverso de la impedancia, con su parte real $\operatorname{Re}(\mathrm{Y})$ (reactancia) e imaginaria $\operatorname{Im}(\mathrm{Y})$ (susceptancia). La regresión lineal de $\operatorname{Re}(Y)$ frente a la altura $h_{i}$ para cada frecuencia nos permite calcular el valor de la pendiente y del término independiente. La pendiente es la reactancia intrínseca $\operatorname{Re}\left(\mathrm{Y}_{\mathrm{h}}\right)$ de la muestra por unidad de altura. Se ha procedido de igual manera para obtener la susceptancia intrínseca $\operatorname{Im}\left(Y_{h}\right)$. Este procedimiento nos permite eliminar todos los factores que no están relacionados con el volumen de la muestra (bordes, celda, cables y aparatos) y calcular su admitancia intrínseca $Y_{h}=\operatorname{Re}\left(Y_{h}\right)+j \cdot \operatorname{Im}\left(Y_{h}\right)$.
To eliminate the effects outside the mortar, we have measured the impedance $(Z)$ versus height, filling the cell with different heights $\left(h_{i}\right)$ of solution. Impedance at 6 heights have been measured and the two extremes have been discarded. The admittance $(Y)$ as the inverse of impedance is calculated, with its real part $\operatorname{Re}(Y)$ (reactance) and imaginary $\operatorname{Im}(Y)$ (susceptance). Linear regression of $\operatorname{Re}(Y)$ versus the height $h_{i}$ for each frequency allows us to calculate the value of the slope and the independent term. The slope is the intrinsic reactance $\operatorname{Re}\left(Y_{h}\right)$ of the sample per unit height. It has done likewise for the intrinsic susceptance $\operatorname{Im}\left(Y_{h}\right)$. This procedure allows us to eliminate all factors that are unrelated to the volume of the sample (edges, cell, cables and devices) and to calculate its intrinsic admittance $Y_{h}=\operatorname{Re}\left(Y_{h}\right)+j \cdot \operatorname{Im}\left(Y_{h}\right)$. 
En el apartado de resultados se calcularán las propiedades eléctricas microscópicas relacionadas con la microestructura a partir de la impedancia intrínseca del mortero $Z_{h}\left(=1 / Y_{h}\right)$. Esta impedancia incluye la impedancia de la solución de cal y la impedancia debida al contacto electrodo-solución, ambas se eliminarán en el posterior análisis.

\subsection{Ensayos mecánicos y de caracterización mineralógica}

Se realizaron ensayos mecánicos de resistencia a compresión a las edades señaladas. Se utilizaron ocho probetas cúbicas, de $20 \mathrm{~mm}$ de arista, procedentes de la muestra cilíndrica mediante corte con una sierra de diamante. Se ha utilizado una prensa INSTRON 3382 para los ensayos, con una velocidad de carga de $2 \mathrm{~mm} / \mathrm{min}$, y una celda de $100 \mathrm{KN}$. Se recogieron trocitos de mortero procedentes del ensayo de compresión. Se molieron en un molino de bola de óxido de zirconio, modelo Fritsch Analysette 3 Spartan, hasta conseguir una granulometría menor de 80 $\mu \mathrm{m}$; y posteriormente se secaron con acetona. El polvo obtenido se ha sometido a dos técnicas de análisis: a) termogravimetría mediante una termobalanza Mettler-Toledo TGA 850 , en el intervalo $35-600^{\circ} \mathrm{C}$ con una velocidad de calentamiento de $10^{\circ} \mathrm{C} / \mathrm{min}$, usando crisoles de aluminio sellados (16) con una tapa microperforada; y b) difracción de rayos X usando el equipo Philips PW1710.

\section{RESULTADOS Y DISCUSIÓN}

\subsection{Propiedades eléctricas microscópicas}

La relación entre propiedades eléctricas y microestructura se basa en el desplazamiento y acumulación de la carga eléctrica. Los fenómenos eléctricos involucrados son: la corriente de iones en la solución de los poros, la acumulación de iones en las interfases y la polarización de las moléculas. Este comportamiento eléctrico se cuantifica con la resistencia eléctrica en corriente continua $\left(R_{d c}\right)$ y con la capacidad eléctrica (C).

La resistencia $R_{d c}$ refleja la dificultad del movimiento de los iones en la solución de los poros conectados cuando se aplica un campo eléctrico. Es una propiedad macroscópica que nos permite calcular la resistividad $\rho$ como el cociente entre $R_{d c} y$ el factor geométrico de la muestra $F[1]$ :
In the section of results will calculate the microscopic electrical properties related to microstructure from the intrinsic impedance of the mortar $Z_{h}\left(=1 / Y_{h}\right)$. This $Z_{h}$ includes the impedance of the lime solution and the impedance due to electrode-solution contact, both were eliminated in subsequent analysis.

\subsection{Mechanical testing and mineralogical characterization}

Mechanical testing of compressive strength were performed at ages indicated. Eight cubic specimens were used, $20 \mathrm{~mm}$ on a side, from the cylindrical sample by cutting with a diamond saw. A press INSTRON 3382 was used for testing with an upload speed of $2 \mathrm{~mm} /$ min and a cell of $100 \mathrm{KN}$. Mortar pieces were collected from the compression test. They were ground in a ball mill zirconium oxide, Fritsch analysette 3 Spartan model, until a particle size less than $80 \mu \mathrm{m}$ and then they were dried with acetone. The powder obtained has undergone two analysis techniques: a) thermogravimetry through a TGA thermobalance Mettler-Toledo 850 in the range $35-600^{\circ} \mathrm{C}$, with a heating rate of $10{ }^{\circ} \mathrm{C} / \mathrm{min}$, using sealed aluminum crucibles with a lid microperforated (16); and b) X-ray diffraction using the equipment Philips PW1710.

\section{RESULTS AND DISCUSSION}

\subsection{Microscopic electrical properties}

The relationship between microstructure and electrical properties is based on the movement and accumulation of electric charge. Electrical phenomena involved are: the flow of ions in the pore solution, the accumulation of ions at interfaces and the polarization of molecules. This electrical behaviour is quantified with the dc electrical resistance $\left(R_{d c}\right)$ and electrical capacitance $(C)$.

Resistance $R_{d c}$ reflects the difficulty of the movement of ions in the solution of connected pores when an electric field is applied. It is a macroscopic property that allows us to calculate the resistivity $\rho$ as the ratio between $R_{d c}$ and geometric factor of the sample $F[1]$ :

$$
\rho=R_{d c} \cdot F^{-1}
$$

F es el cociente entre la longitud promedio de las líneas de campo eléctrico y el valor promedio del área atravesada por dichas líneas. El factor geométrico por unidad de altura es $F=[\operatorname{Ln}(a / b)] /(2 \cdot \pi)$, donde $a$ y $b$ son los radios exterior e interior de la muestra cilíndrica. La resistividad $\rho$ es una propiedad intrínseca del mortero
$F$ is the ratio between the average length of the electric field lines and the average value of the area traversed by these lines. The geometric factor per unit height is $F=[\operatorname{Ln}(a / b)] /(2 \cdot \pi)$, where $a$ and $b$ are the outer and inner radii of the cylindrical sample. The resistivity $\rho$ is an intrinsic property of the mortar independent of 
independiente de la frecuencia relacionada con la porosidad conectada (tamaño de poro y tortuosidad) y con la resistividad de la solución del poro.

La capacidad eléctrica $C$ determina la distancia de separación de las cargas eléctricas opuestas cuando se aplica un campo eléctrico. Esta propiedad depende de la frecuencia de oscilación $\mathrm{f}$ (hercios, $\mathrm{Hz}$ ) del campo eléctrico. La capacidad determina la distancia de separación de los iones en la solución del poro, la cual está limitada por la superficie de los electrodos a frecuencias inferiores a $2 \mathrm{kHz}$ y por el tamaño del poro bloqueado a frecuencias superiores (10 kHz-1 MHz). La capacidad (23) puede escribirse como [2]: frequency, which depends on the connected porosity (pore size and tortuosity) and resistivity of the pore solution.

The electrical capacitance $C$ determines the separation of opposite electric charges when an electric field is applied. This property depends on the oscillation frequency $f$ (hertz, Hz) of electric field. Capacitance determines the separation of ions in the pore solution, which is limited by the surface of the electrodes at frequencies below $2 \mathrm{kHz}$ and by the size of blocked pore at higher frequencies $(10 \mathrm{kHz}-1 \mathrm{MHz})$. The capacitance (23) can be written as [2]:

$$
C(\omega)=T \cdot(j \omega)^{\alpha-1}=\varepsilon(\omega) \cdot F^{-1}
$$

donde $\omega$ es la frecuencia angular $(\omega=2 \pi \cdot f$, en $\mathrm{rad} / \mathrm{s})$, $j=\sqrt{ }(-1)$ y $\varepsilon(\omega)$ es la permitividad dieléctrica. T es el factor capacitivo (faradios/(rad/s $)^{\alpha-1}$ ) relacionado con la porosidad de la superficie del electrodo metálico a baja frecuencia y con la porosidad cerrada a frecuencias superiores. El exponente capacitivo $\alpha$ (sin unidades) determina la fractalidad de la superficie de los electrodos (a baja frecuencia) y la distribución fractal del poro bloqueado del mortero (a frecuencias más altas) (24).

En este trabajo hemos admitido que la conducción eléctrica del mortero en el rango de frecuencia utilizado se explica por un modelo físico de dos regiones porosas en paralelo: la porosidad conectada y la porosidad bloqueada (por la fase sólida y por los productos de hidratación) (24). La admitancia eléctrica resultante es la suma de las admitancias en paralelo [3]: where $\omega$ is the angular frequency $(\omega=2 \pi \cdot f$ in rad $/ s)$, $j=\sqrt{ }(-1)$ and $\varepsilon(\omega)$ is the dielectric permittivity. $T$ is the factor of capacitance (farads / ( rad / s) ${ }^{\alpha-1}$ ) related to the porosity of the metal electrode surface at low frequencies and related to the closed porosity at higher frequencies. The capacitive exponent $\alpha$ (no units) determines the fractality of the electrode surface (low frequency) and the blocked pore fractal distribution of the mortar (at higher frequencies) (24).

In this work we have assumed that the electrical conductivity of the mortar in the frequency range used is explained by a physical model of two porous regions in parallel: the connected porosity and porosity blocked (by the solid phase and the hydration products) (24). The resulting electrical admittance is the sum of the admittances in parallel [3]:

$Y(\omega)=Y_{\text {conec }}+Y_{\text {bloq }}=(1 / \rho) \cdot F^{-1}+(j \omega) \cdot C(\omega)=(1 / \rho) \cdot F^{-1}+T \cdot(j \omega)^{\alpha}=\left[(1 / \rho) \cdot F^{-1}+T \cdot \omega^{\alpha \cdot} \cdot \cos (\alpha \cdot \pi / 2)\right]+j \cdot\left[T \cdot \omega^{\alpha \cdot} \cdot \operatorname{sen}(\alpha \cdot \pi / 2)\right]$

La Figura 2 a), b) y c) muestra la gráfica de la impedancia compleja (Im[Z] vs Re[Z]), medida entre $20 \mathrm{~Hz}$ y 1 $\mathrm{MHz}$ (59 datos), para todos los tipos de mortero ensayados, con 3 días de hidratación. Se han representado los espectros de las cuatro alturas medidas $\left(h_{\mathrm{i}}\right)$. La forma de las curvas es similar, pero desplazada en el eje real hacia valores menores de $\operatorname{Re}[Z]$ según aumenta $h_{\mathrm{j}}$. En cada curva el menor valor de $\operatorname{Im}[Z]$ corresponde a la menor frecuencia $(20 \mathrm{~Hz})$. Al aumentar la frecuencia aumenta la parte imaginaria hasta un máximo (próximo a cero) para disminuir después ligeramente. La impedancia disminuye al aumentar la altura debido a que el área transversal al campo eléctrico aumenta con la altura. Se observa que el mayor valor de Re[Z] pertenece a MK y el menor corresponde a CONTROL, para cualquier altura y a todas las frecuencias.

La Figura 2 d) muestra la impedancia intrínseca $Z_{h}$ (apartado 2.2) de los tres tipos de mortero, representada en el plano complejo. En todas las muestras se observan dos ramas, en la baja y alta frecuencia, respectivamente.
Figure $2 a), b)$ and c) shows the graph of the complex impedance (Im[Z] vs. Re[Z]), measured between $20 \mathrm{~Hz}$ and $1 \mathrm{MHz}$ (59 data) for all types mortar tested, with 3 days of hydration. The spectra of the four measured heights $\left(h_{i}\right)$ are shown. The shape of the curves is similar, but shifted in the real axis towards lower values of $\operatorname{Re}[Z]$ with increasing $h_{j}$. In each curve the lowest value of Im[Z] corresponds to the lowest frequency (20 $\mathrm{Hz}$ ). With increasing frequency the imaginary part increases to a maximum (near zero) and then decreased slightly. The impedance decreases by increasing the height, due to transverse area to electric field increases with heigth. It is noted that the highest value of $\operatorname{Re}[Z]$ belongs to MK and lowest in CONTROL, for any height and all frequencies.

Figure 2 d) shows the intrinsic impedance $Z_{h}$ (section 2.2) of the three types of mortar, represented in the complex plane. In all samples there are two branches in low and high frequency, respectively. The maximum 
El valor máximo de $\operatorname{Im}\left[\mathrm{Z}_{\mathrm{h}}\right]$, donde las dos ramas se unen, corresponde a una frecuencia intermedia (2-10 kHz). La rama de baja frecuencia representa la impedancia de la interfase electrodo-solución, la cual es independiente del mortero. La forma de la rama de alta frecuencia $(10 \mathrm{kHz}-$ $1 \mathrm{MHz}$ ) es característica de un elemento resistivo en paralelo con un elemento capacitivo, justificando el modelo con dos tipos de porosidad en paralelo. Estos elementos eléctricos determinan las propiedades eléctricas intrínsecas del material $(\rho$, T y $\alpha)$ que se calculan en los siguientes apartados. value of $\operatorname{Im}\left[Z_{h}\right]$, where the two branches meet, corresponds to an intermediate frequency $(2-10 \mathrm{kHz})$. The low frequency branch represents the impedance of the electrode-solution, which is independent of the mortar. The shape of the branch of high frequency $(10 \mathrm{kHz}-1 \mathrm{MHz})$ is characteristic of a resistive element in parallel with a capacitive element, justifying the model with two types of porosity in parallel. These electric elements determine the intrinsic electrical properties of the material ( $\rho, T$ and $\alpha$ ) which are calculated in the following paragraphs.

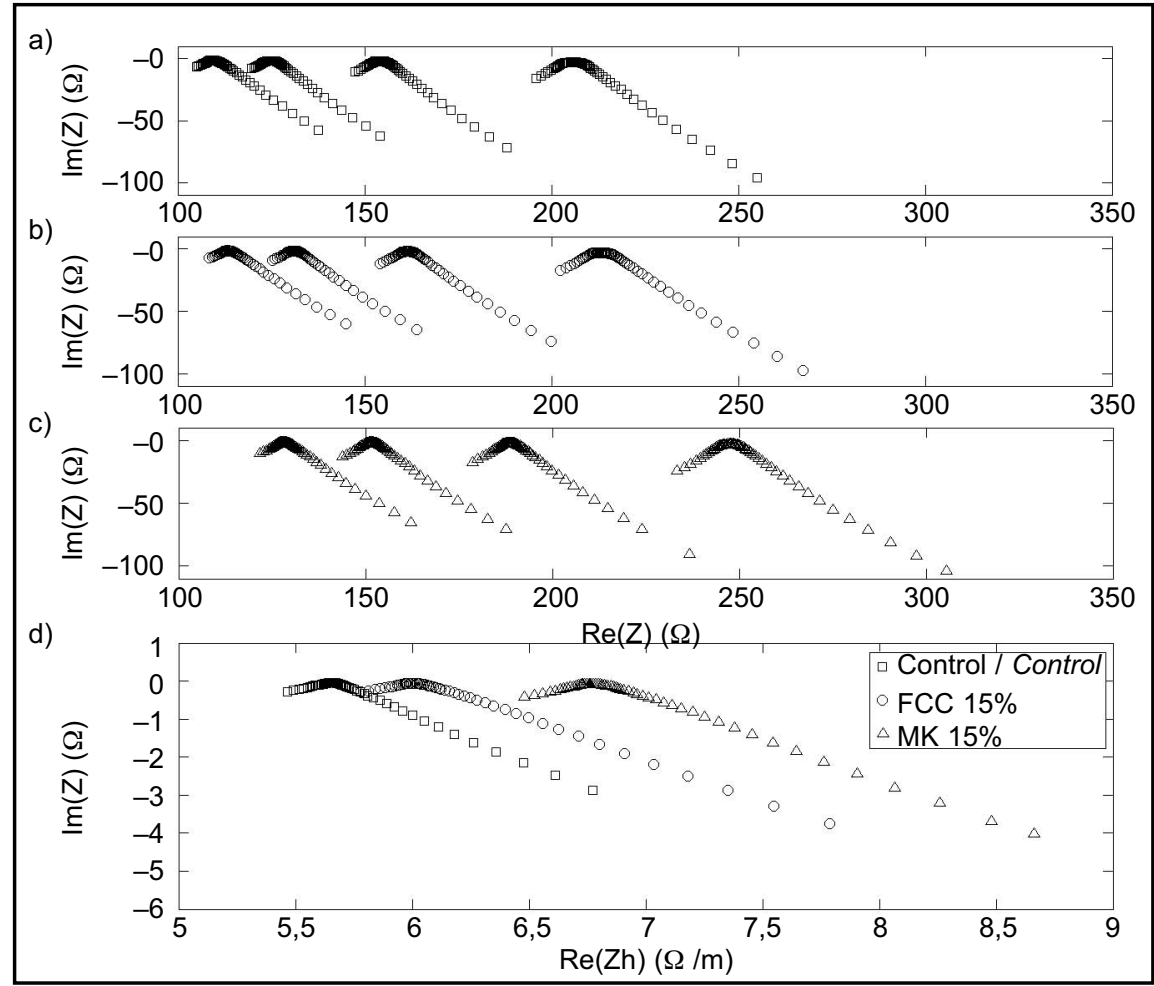

Figura 2. Representación compleja de la impedancia $\operatorname{Im}[Z]$ vs Re[Z] a la edad de 3 días de cada tipo de mortero: a) CONTROL, b) FCC, c) MK, para cuatro alturas de medida (de derecha a izquierda aumenta la altura) y d) Impedancia intrínseca para los tres tipos de morteros.

Figure 2. Complex plot of impedance Im[Z] versus Re[Z] for 3-days curing of each type mortar: a) CONTROL, b) FCC, c) MK for four depth of measurement (right to left depth rise) and d) Intrinsic impedance for all mortars.

\subsection{Resistividad eléctrica $(\rho)$}

La resistividad eléctrica $\rho$ se ha obtenido a partir de la Ecuación [1], tomando $R_{d c}$ como la diferencia entre el valor de $\operatorname{Re}\left[Z_{h}\right]$ cuando $\left|\operatorname{Im}\left(Z_{h}\right)\right|$ es mínimo y la resistencia eléctrica de la solución de la celda. El valor de $\rho$ se identifica con la resistividad eléctrica de la fase porosa conectada del mortero, en la que intervienen el volumen de la porosidad, su geometría y la solución del poro.

En la Tabla 2 figuran los valores de $\rho$ para los tres tipos de mortero entre los días 1 y 148 de hidratación. Estos valores tienen un error estándar de $1 \%$ que se ha determinado repitiendo 9 veces la medida de una misma muestra.

\subsection{Electrical resistivity $(\rho)$}

The electrical resistivity $\rho$ was obtained from Equation [1] taking $R_{d c}$ as the difference between the value of $\operatorname{Re}\left[Z_{h}\right]$ when / Im $\left(Z_{h}\right)$ / is minimal and the electrical resistance of the cell measurement solution. The value of $\rho$ is identified with the electrical resistivity of the connected porous mortar phase, which involves the porosity volume, its geometry and pore solution.

Table 2 shows values of $\rho$ for the three types of mortar between 1 and 148 of hydration. These values have a standard error of $1 \%$ which is determined by repeating 9 times the measure of the same sample. 
Tabla 2 / Table 2

Valores medios de $\rho(\Omega \mathrm{m})$, $\alpha$ y $\mathrm{T}(\mathrm{F} /(\mathrm{rad} / \mathrm{s}) \alpha-1)$ para algunos días de curado de los tres tipos de mortero. El error estándar es $1 \%$, $2 \%$ y $7 \%$, respectivamente.

Average values of $\rho(\Omega m), \alpha$ y $T(F /(r a d / s) \alpha-1)$ for certain curing days and for all three mortars. Standard error is $1 \%$, $2 \%$ y $7 \%$, respectively.

\begin{tabular}{|c|c|c|c|c|c|c|c|c|c|}
\hline \multirow{2}{*}{$\begin{array}{c}\text { Tiempo / Time } \\
\text { (día / day) }\end{array}$} & \multicolumn{3}{|c|}{ Control / Control } & \multicolumn{3}{c|}{ FCC 15\% } & \multicolumn{3}{c|}{ MK 15\% } \\
\cline { 2 - 10 } & $\boldsymbol{\rho}$ & $\boldsymbol{\alpha}$ & $\mathbf{T}$ & $\boldsymbol{\rho}$ & $\boldsymbol{\alpha}$ & $\mathbf{T}$ & $\boldsymbol{\rho}$ & $\alpha$ & $\mathbf{T}$ \\
\hline 1 & 14.2 & 0.50 & $4.20 \cdot 10^{-6}$ & 13.5 & 0.38 & $2.85 \cdot 10^{-5}$ & 13.9 & 0.46 & $3.43 \cdot 10^{-6}$ \\
\hline 3 & 19.1 & 0.66 & $6.67 \cdot 10^{-7}$ & 21.0 & 0.59 & $5.42 \cdot 10^{-7}$ & 22.8 & 0.64 & $2.36 \cdot 10^{-7}$ \\
\hline 7 & 26.3 & 0.72 & $1.44 \cdot 10^{-7}$ & 44.2 & 0.75 & $7.54 \cdot 10^{-8}$ & 87.4 & 0.79 & $5.61 \cdot 10^{-8}$ \\
\hline 14 & 29.6 & 0.73 & $1.20 \cdot 10^{-7}$ & 90.5 & 0.79 & $6.07 \cdot 10^{-8}$ & 233.3 & 0.75 & $9.58 \cdot 10^{-8}$ \\
\hline 148 & 41.8 & 0.76 & $8.63 \cdot 10^{-8}$ & 243.4 & 0.75 & $1.14 \cdot 10^{-7}$ & 561.4 & 0.74 & $1.13 \cdot 10^{-7}$ \\
\hline
\end{tabular}

La Figura 3 a) y b) representa los valores de $\rho$ de los tres tipos de mortero en función del tiempo de hidratación, en escala semilogarítmica. El mortero CONTROL (Figura 3a) muestra un comportamiento lineal en el periodo 1148 días de hidratación con un coeficiente de determinación $\mathrm{R}^{2}=0,985$. La pendiente de la recta es $13,25 \Omega \cdot \mathrm{m}$ y el término independiente del tiempo es $13,94 \Omega \cdot \mathrm{m}$ (resistividad del primer día). Este aumento lineal de $\rho$ en escala semi-logarítmica también ha sido encontrado en medidas eléctricas sin electrodos entre 1 y 3 días de hidratación (25). Por otra parte, también se ha observado una variación lineal semi-logarítmica del contenido de gel CSH (26), el cual está relacionado con la reducción
Figure $3 a$ ) and b) represent the values of $\rho$ of the three types of mortar as a function of hydration time in semilogarithmic scale. The mortar CONTROL (Figure 3a) shows a linear behaviour in the period 1-148 days of hydration with a coefficient of determination $R^{2}=0.985$. The slope of the line is $13.25 \Omega \cdot m$ and the timeindependent term is $13.94 \Omega \cdot \mathrm{m}$ (resistivity of the first day). This linear increase in $\rho$ semi-log scale has also been found in electrical measurements without electrodes between 1 and 3 days of hydration (25). Moreover, it has also been a semi-logarithmic linear variation of the content of $\mathrm{CSH}$ gel (26), which is related to the reduction of open porosity and therefore with the

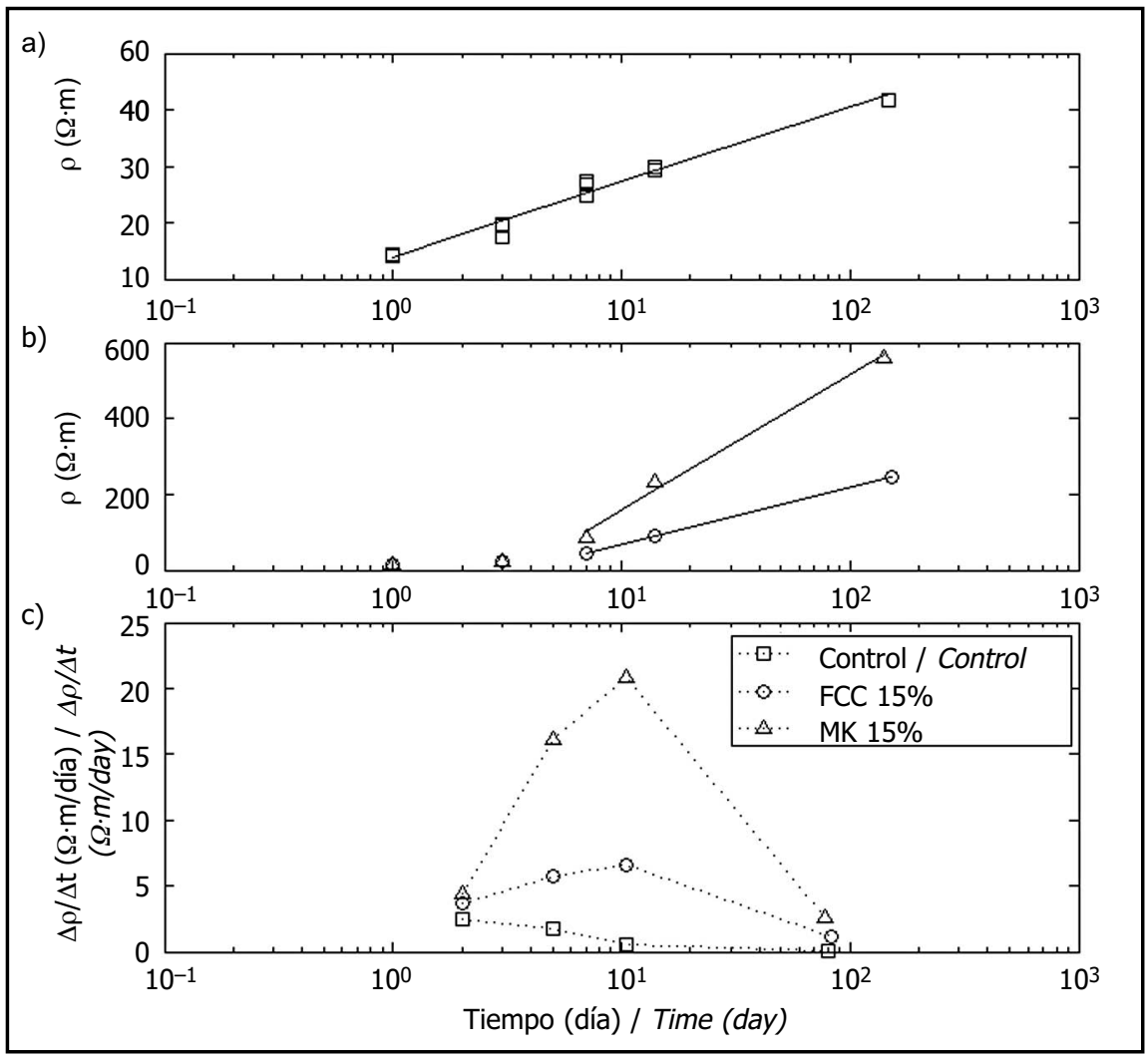

Figura 3. a) y b) Representación de la variación de la resistividad $\rho$ con la edad de curado para los diversos especímenes de mortero (escala semi-logarítmica), c) velocidad de la resistividad con la edad de curado.

Figure 3. a) and b) Plot of resistivity versus curing age for all types of mortar (semi-logarithmic scale), c) velocity of resistivity versus curing age. 
de la porosidad abierta y por tanto con el aumento de la resistividad eléctrica. La resistividad de los morteros FCC y MK se muestran en la Figura 3 b). A diferencia del mortero CONTROL las sustituciones provocan un comportamiento no lineal a edad temprana ( 1 a 7 días) y un comportamiento lineal en el periodo final de 7 a 148 días. Los valores de las pendientes son claramente superiores a CONTROL, el FCC con un valor de $149 \Omega \cdot \mathrm{m}$ y el MK con $363 \Omega \cdot m$, ambos con $\mathrm{R}^{2}>0,98$.

Podemos observar en la Tabla 2 que el valor de $\rho$ es similar para los tres morteros el primer día de curado, teniendo en cuenta su incertidumbre ( 2 veces el error estándar): $14,2 \pm 0,3 ; 13,5 \pm 0,3$ y $13,9 \pm 0,3 \Omega \cdot m$. Las diferencias significativas entre los tres tipos de mortero se observan a partir del día 3. El FCC y el MK han aumentado el valor de $\rho$ hasta un $20 \%$ entre día 1 y día 3 . A partir del día 7 las diferencias en la resistividad son cada vez mayores hasta llegar a la máxima diferencia el día 148 , en que el cociente de la resistividad vs CONTROL es 5,8 para FCC y 13,4 para MK (17). El valor de $\rho$ en los morteros depende de la porosidad abierta y de la solución del poro, sin embargo la variación debida a la resistividad de solución de poro únicamente afecta en la primera hora de hidratación (25). Por tanto la elevada resistividad de los morteros FCC y MK en relación con el mortero CONTROL se puede relacionar con la disminución de la porosidad conectada, como resultado de la actividad puzolánica. Las partículas puzolánicas reaccionan con la portlandita, dando lugar a una mayor cantidad de productos hidratados en la fase porosa, aumentando la tortuosidad y generando una matriz más densa.

La tasa de aumento de $\rho$ con el tiempo de curado (velocidad de $\rho$ ) se muestra en la Figura 3c). A pesar de las diferencias en los valores de $\rho$ entre los tres morteros, no se observan grandes diferencias en las velocidades en los primeros tres días (menos de $5 \Omega \mathrm{m} /$ día) ni entre los días 14 y 148, en los que la velocidad vuelve a ser inferior a $5 \Omega \cdot \mathrm{m} /$ día. La gran diferencia de la velocidad de la resistividad entre los tres morteros se observa en el periodo 3-14 días. Mientras que en el mortero CONTROL la velocidad de $\rho$ disminuye monótonamente desde 3 $\Omega \mathrm{m} /$ día hasta un valor prácticamente nulo, el FCC tiene un máximo de velocidad igual a 6,5 y el MK tiene un máximo igual a $20,7 \Omega \mathrm{m} /$ día entre los días 7 y 14 . Estos datos sugieren que el máximo de la actividad puzolánica de las dos sustituciones: FCC y MK, se encuentra en la segunda semana de hidratación. La velocidad máxima del mortero MK es tres veces la del FCC, indicando una mayor reactividad de las partículas de MK, debido, probablemente, a la mayor finura. El diámetro medio de las partículas es $5,84 \mu \mathrm{m}$ para MK y $19,73 \mu \mathrm{m}$ para FCC (Tabla 1). Las curvas de velocidad para los morteros con FCC y con MK tienen un máximo alrededor del día 10 y son análogas a la ecuación de Avrami para la variación increased electrical resistivity. The resistivity of the mortars FCC and MK are shown in Figure 3 b). Unlike the CONTROL mortar substitutions cause a nonlinear behaviour at a young age (1 to 7 days) and a linear behaviour in the final period of 7 to 148 days. Slope values are much higher than CONTROL, FCC with slope value $149 \Omega \cdot m$ and $M K$ with $363 \Omega \cdot \mathrm{m}$, both with $R^{2}>$ 0.98 .

We can observe in Table 2 that the value of $\rho$ is similar for the three mortars at the first day of curing, by taking into account their uncertainty (2 times the standard error): $14.2 \pm 0.3,13.5 \pm 0,3$ and $13.9 \pm 0.3 \Omega \cdot \mathrm{m}$. The significant differences between the three types of mortar are observed from day 3. FCC and MK have increased the value of $\rho$ up to $20 \%$ between day 1 and day 3 . From day 7 the differences in resistivity are growing up to the maximum difference on 148, where the value of the resistivity of FCC is 5.8 and $M K$ is 13.4 times the resistivity of CONTROL, respectively (17). The value of $\rho$ in mortars depends on the porosity and pore solution, however the variation due to the resistivity of pore solution affects only the first hour of hydration (25). Thus the high resistivity of the mortars FCC and MK in relation to the CONTROL mortar may be related to the decrease in porosity connected, as a result of pozzolanic activity. The pozzolanic particles react with the portlandite, resulting in a greater amount of hydrated products in the porous phase, increasing the tortuosity and generating a dense matrix.

The rate of increase of $\rho$ with the curing time (speed of $\rho$ ) is shown in Figure 3c). Despite the differences in $\rho$ values between the three mortars, there are no great differences in rates in the first three days (less than $5 \Omega \mathrm{m} /$ day) and between days 14 and 148, where the speed becomes to be less than $5 \Omega \mathrm{m} /$ day. The great difference in the speed of resistivity between the three mortars is observed in the period 3-14 days. While in the CONTROL mortar speed of $\rho$ decreases monotonically from $3 \Omega \mathrm{m} /$ day to a virtually zero value, the FCC has a maximum speed equal to 6.5 and the $M K$ has a maximum equal to $20.7 \Omega \mathrm{m} /$ day between days 7 and 14. These data suggest that the maximum pozzolanic activity of the two substitutions: FCC and MK, is in the second week of hydration. The maximum speed of MK mortar is three times that of the FCC, indicating a higher reactivity of $M K$ particles, probably due to the greater finesse. The average particle diameter is $5.84 \mu \mathrm{m}$ for MK and $19.73 \mu \mathrm{m}$ for FCC (Table 1). Speed curves for mortars with FCC and with MK, have a maximum around day 10 and they are similar to the Avrami equation for varying degree of hydration, which responds to a model of nucleation and growth (27). To 
del grado de hidratación, que responde a un modelo de nucleación y crecimiento (27). Para diferenciar las etapas de aceleración (nucleación-crecimiento) y de desaceleración (control de la hidratación por difusión de reactantes a través de la fase CSH), y para localizar el día de máxima velocidad, habría que tomar más medidas de resistividad en el periodo 7-148 días.

\subsection{Exponente capacitivo ( $\alpha)$}

El exponente capacitivo $\alpha$ de las ecuaciones [2] y [3] se obtiene calculando la pendiente de la recta de regresión lineal: $\log \left(\operatorname{Im}\left[Y_{h}\right]\right)$ frente a $\log (\omega)$. Tomamos los 16 últimos valores del espectro, entre $63 \mathrm{kHz}$ y $1 \mathrm{MHz}$, debido a que en este intervalo de frecuencia la relación es altamente lineal y la admitancia de la interfase electrodo-solución es despreciable. Todas las regresiones tienen un $\mathrm{R}^{2}>0,98$. En la Tabla 2 y en la Figura 4 se muestra el valor de $\alpha$ para los tres tipos de mortero en función del tiempo de hidratación (error estándar del 2\%). El exponente capacitivo de CONTROL aumenta monótonamente durante el periodo de hidratación desde 0,5 en el día 1 hasta 0,76 el día 148 . El FCC comienza con el valor más bajo a día $1(0,38)$, aumenta hasta el día 14 con un valor máximo de 0,79 y desciende hasta un valor de 0,75 el día 148. El MK tiene un comportamiento similar al FCC. Comienza el día 1 con un valor entre CONTROL y $\operatorname{FCC}(0,46)$. Alcanza el máximo $(0,79)$ igual que FCC pero adelantado al día 7 y disminuye hasta un valor de 0,74 el día 148 . Si aplicamos la incertidumbre del $4 \%$ ( 2 veces el error estándar) a los valores de referencia del mortero CONTROL, obtenemos los intervalos de error para los 5 días de medición: 1:(0,48-0,52), $3:(0,63-0,69), 7:(0,69-0,75), 14:(0,70-0,76)$ y $148:(0,73-$ $0,79)$. Podemos afirmar que los valores del primer día de FCC $(0,38)$ y MK $(0,46)$ son inferiores a los de CONTROL. Así mismo los valores máximos de 0,79 en los días 7 (MK) y 14 (FCC) son superiores a los obtenidos para CONTROL en esos mismos días. Por otra parte no podemos decir que haya diferencias significativas entre los tres morteros el día 148. distinguish the stages of acceleration (nucleationgrowth) and deceleration (hydration control by diffusion of reactants through the $\mathrm{CSH}$ phase), and to locate the day of maximum speed, more resistivity measurements in period 7 - 148 days should be taken.

\subsection{Capacitive exponent $(\alpha)$}

The capacitive exponent $\alpha$ of equations [2] and [3] is obtained by calculating the slope of the linear regression of $\log \left(\operatorname{Im}\left[Y_{h}\right]\right)$ versus $\log (\omega)$. We took the last 16 values of the spectrum, between $63 \mathrm{kHz}$ and $1 \mathrm{MHz}$, because in this frequency range the relationship is highly linear and admittance of the electrode-solution is negligible. All regressions have an $R^{2}>0.98$. Table 2 and Figure 4 shows the value of $\alpha$ for the three types of mortar as a function of hydration time (standard error of 2\%). Capacitive exponent for CONTROL, increases monotonically during the hydration period from 0.5 on day 1 to 0.76 on 148. FCC begins with the lowest value at day 1, 0.38; increases until day 14 with a maximum value of 0.79 and drops to a value of 0.75 on 148 . MK has a behaviour similar to FCC. MK starts on day 1 with a value of 0.46 , between CONTROL and FCC. It reaches the maximum (0.79) equal to FCC but advanced to day 7 and it decreases to a value of 0.74 on 148. Applying the uncertainty of $4 \%$ (2 times the standard error) to the reference values of CONTROL mortar, we get the error intervals for the 5 days of measurement: $1:(0,48-0,52)$, $3:(0,63-0,69), \quad 7:(0,69-0,75), \quad 14:(0,70-0,76) \quad y$ $148:(0,73-0,79)$. We can say the values of the first day of FCC (0.38) and MK (0.46) are lower than CONTROL. Also the maximum values of 0.79 on day $7(M K)$ and 14 (FCC) are higher than those obtained for CONTROL in those days. On the other hand we can not say that there are significant differences among the three mortars on 148.

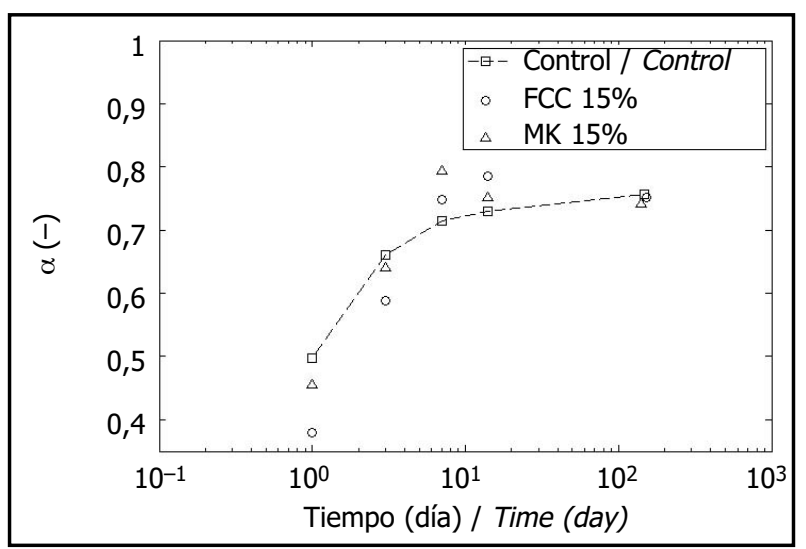

Figura 4. Exponente capacitivo $\alpha$ para los tres tipos de mortero en función del tiempo de hidratación.

Figure 4. Capacitive exponent $\alpha$ versus curing age for all types of mortar. 
Este exponente $\alpha$ está relacionado con el parámetro D de la distribución fractal del tamaño de los poros bloqueados según la relación: $D=2 \alpha+1$ [24]. Para el CONTROL, $D=2$ el día 1 y aumenta hasta un valor de 2,5 el día 148. Estos valores coinciden con los medidos mediante diversas técnicas de evaluación de la geometría de la microestructura (28-31). La evolución de D en CONTROL refleja un incremento monótono de la varianza del tamaño del poro durante la hidratación.

La geometría de la porosidad bloqueada de los morteros con sustituciones evoluciona de forma diferente. EI FCC en su primer día tiene un valor $(1,76)$ inferior que el valor de CONTROL $(2,00)$ lo que significa que FCC tiene la porosidad más uniforme. La hidratación está menos evolucionada, lo cual indica que la reacción puzolánica en FCC todavía no ha empezado a día 1. Además, las partículas inactivas de FCC cambian la porosidad del mortero. El MK tiene $D=1,92$ a día 1 , que aunque es ligeramente inferior a CONTROL, es superior a FCC, debido al menor tamaño de partícula. Estos resultados del primer día son coherentes con medidas de porosidad, según las cuales los morteros con sustituciones puzolánicas tienen mayor porosidad que los morteros de cemento (32). A partir del día 1 tanto MK como FCC aumentan el valor de $D$, hasta conseguir sus valores máximos en las dos primeras semanas. El MK exhibe un máximo el día 7 y el FCC lo tiene el día 14, ambos superiores a CONTROL. Estos elevados valores de $D$ indican que hay una actividad puzolánica de las sustituciones y que el MK se activa a edades más tempranas que el FCC, con el $15 \%$ de sustitución. Al avanzar la hidratación, hacia el día 148, la porosidad de los tres tipos de mortero alcanzan una distribución de tamaño de poro con una dispersión similar $\mathrm{D}=2,5$.

\subsection{Factor capacitivo (T)}

El factor capacitivo T se obtiene del término independiente de la recta de regresión calculada para determinar el exponente $\alpha$. En la Tabla 2 figura el valor de $T$ para todos los morteros con la edad de curado (error estándar del 7\%). El factor capacitivo $\mathrm{T}$ es proporcional a la cantidad de porosidad bloqueada, cuyo tamaño medio de poro es observable en el intervalo de frecuencia utilizado (24). En la Figura 5 se representa el parámetro microscópico capacitivo T.F frente al tiempo de curado. Según la ecuación [2], T·F es función de la permitividad dieléctrica del mortero y es independiente de la forma y dimensiones de la muestra. El valor de T.F medido en CONTROL disminuye monótonamente de día 1 a 148 , resultado que está de acuerdo con los datos de SS Yoon et al (24).

A día 1, FCC tiene un valor de T.F claramente superior a CONTROL y MK, poniendo de manifiesto la diferencia de
This exponent $\alpha$ is related to the parameter $D$ of the fractal distribution of pore size blocked by the relationship: $D=2 \alpha+1$ [24]. For CONTROL, $D=2$ on day 1 and increases to a value of 2.5 on 148. These values match those measured by various techniques for evaluating the geometry of the microstructure (28-31). The increase in D for CONTROL means that the variance of pore size increases monotonically with the evolution of hydration.

The geometry of the blocked porosity of mortars with substitutions evolves differently. FCC has a value $D=1.76$ at first day, lower than the CONTROL value $D=2$, which means that FCC has more uniform porosity than CONTROL. Hydration is less evolved, indicating that the pozzolanic reaction in FCC still has not started at day 1. Moreover, the inactive particles of FCC changes the porosity of the mortar. MK has $D=1.92$, which although slightly lower than CONTROL exceeds FCC, due to the smaller particle size. These results on first day are consistent with the porosity measurements, according to which the mortars with pozzolanic substitutions are more porous than plain cement mortars (32). From day 1, both $M K$ and FCC increase the value of $D$ to achieve their peak in the first two weeks. MK exhibits a maximum on day 7 and FCC has it on the 14th, both higher than CONTROL. These high $D$ values indicate a pozzolanic activity of the substitutions and that MK is activated at an earlier age than FCC, with our 15\% substitution. Later in the hydration, on day 148, the porosity of the three types of mortar reach a pore size distribution with a similar spread, $D=2.5$.

\subsection{Capacitive Factor (T)}

The capacitive factor $T$ is obtained from independent term of the regression line calculated to determine the exponent $\alpha$. Table 2 lists the value of $T$ for all mortars with curing age ( $7 \%$ standard error). The capacitive factor $T$ is proportional to the amount of blocked porosity, whose average pore size is observable in the frequency range used (24). Figure 5 shows the microscopic capacitive parameter $T \cdot F$ versus curing time. From Equation [2], T.F is a function of the dielectric permittivity of the mortar and is independent of the shape and dimensions of the sample. The T.F value measured in CONTROL decreases monotonically from day 1 to 148 , in agreement with the data of Yoon SS et al (24).

At day 1, FCC has a value of T.F significantly higher than CONTROL and MK, showing the size difference between 


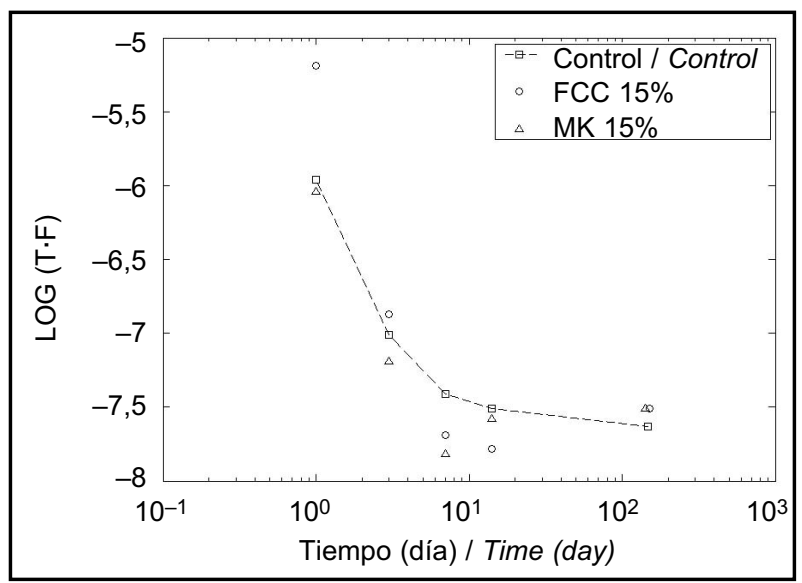

Figura 5. Factor capacitivo T.F frente al tiempo de curado. $F=0,30 \mathrm{~m}^{-1}$ es el factor geométrico de la muestra. Figure 5. Capacitive factor T.F versus curing age. $F=0,30 \mathrm{~m}^{-1}$ is geometric factor of the sample.

tamaño entre las partículas de FCC y MK. Desde el primer día el valor de T.F disminuye para los tres tipos de mortero hasta un mínimo en día 7, a partir de entonces no hay ni variación ni tampoco diferencias significativas. La evolución de T.F indica que la porosidad cerrada disminuye para los tres tipos de mortero en el periodo de mediciones, lo que significa que la hidratación ha reducido el tamaño de los poros bloqueados hasta valores que resultan indetectables a la frecuencia de $1 \mathrm{MHz}$.

\subsection{Reacción puzolánica y resistencia mecánica a compresión}

La adicción de materiales puzolánicos origina varios efectos en la microestructura: i) reducción de la portlandita producida en la hidratación del cemento, debido a la combinación química con los componentes reactivos ácidos de la puzolana, ii) aparición de mayores cantidades de hidratos del tipo CSH por reacción de la fracción silícea reactiva de la puzolana, iii) aparición de hidratos del tipo silicoaluminato cálcico hidratado (gehlenita hidratada o estratlingita) cuando la puzolana contiene alúmina reactiva, como es el caso de FCC y de MK (33), iv) reducción de la porosidad de la matriz cementante, por formación de una cantidad adicional de hidratos, y v) mejora de la resistencia mecánica a compresión como consecuencia del aumento en la cantidad de hidratos y del refinamiento de la estructura porosa.

En esta parte del trabajo hemos realizado dos estudios: i) químico y mineralógico, ii) mecánico. El primero aplica la difracción de rayos $\mathrm{X}$ y la termogravimetría, en el segundo se mide la resistencia mecánica a compresión.

Hemos evaluado los morteros de 148 días por difracción de rayos $X$. Además de la generalizada presencia de cuarzo en todos los morteros se observan algunas diferencias significativas entre ellos. En el mortero CONTROL se detecta la presencia de portlandita, etringita y silicatos particles of FCC and MK. From day one the value of T.F decreases for the three types of mortar to a minimum at day 7 , after that there is neither change nor significant differences. The evolution of T.F indicates that the closed porosity decreases for the three types of mortar on the measurement period, which means that hydration has reduced the size of the blocked pores to levels that are undetectable to the frequency of $1 \mathrm{MHz}$

\subsection{Pozzolanic reaction and mechanical resistance to compression}

The addition of pozzolanic materials causes several effects on the microstructure: i) the reduction of portlandite produced in the hydration of cement due to chemical combination with acid reactive component of the pozzolan, ii) the emergence of larger amounts of $\mathrm{CSH}$ type hydrates by reacting the reactive silica fraction of the pozzolan, iii) the formation of silicoaluminate calcium hydrate (hydrated gehlenite or estratlingite,) when the reactive pozzolan contains alumina, such as FCC and MK (33), iv) the decrease of porosity in the cementitious matrix by formation of an additional amount of carbohydrates, and $v$ ) the improvement of compressive strength due to increase in the amount of carbohydrates and refinement of the pore structure.

In this part of the work we have conducted two studies: i) chemical and mineralogical ii) mechanical. The first applies $X$-ray diffraction and thermogravimetry, the second measures the compressive strength.

We evaluated the mortars of 148 days by $X$-ray diffraction. It highlights the widespread presence of quartz in all the mortars and some significant differences between them. In CONTROL is detected the presence of portlandite, ettringite and calcium silicate hydrates. In 
cálcicos hidratados. En morteros con sustitución puzolánica se observa portlandita, en ambos casos, lo que significa que la reacción puzolánica no ha podido consumir toda la portlandita. Por ello, cabe pensar que en la solución de los poros de mortero con puzolana se podrá alcanzar un elevado nivel de concentración de $\mathrm{Ca}^{+2} \mathrm{y} \mathrm{OH}^{-}$ correspondiente a la saturación de la disolución. Por tanto el incremento de resistividad eléctrica no se puede atribuir a un descenso en la conductividad de la disolución de los poros sino a un aumento de la tortuosidad. La presencia de portlandita en la matriz cementante está de acuerdo con el bajo porcentaje de sustitución de estos morteros con puzolana ( $15 \%$ en peso). Además, se encuentra estratlingita en el FCC y no se observa en los otros morteros, esto indica que sólo la fracción alúmina reactiva del FCC ha intervenido en la reacción puzolánica.

La técnica de análisis termogravimétrico nos permite identificar y cuantificar los diferentes hidratos presentes en la matriz cementante. Los termogramas de los morteros se han analizado a 7, 14 y 148 días. Se ha calculado el contenido de portlandita con las pérdidas de peso de agua en el rango $450-550^{\circ} \mathrm{C}$ (Tabla 3), y se han observado diferencias entre los diferentes morteros, atribuidas fundamentalmente a la reacción de descomposición [4]: mortars with pozzolanic replacement portlandite is observed in both cases, which means that the pozzolanic reaction could not consume all the portlandite. Therefore, it is conceivable that the pore solution with pozzolana mortar may reach a high concentration of $\mathrm{Ca}^{+2}$ and $\mathrm{OH}^{-}$corresponding to the saturation of the solution. Therefore, the electrical resistivity increase can not be attributed to a decrease in the conductivity of the pore solution but an increase in tortuosity. The presence of portlandite in the cementing matrix agrees with the low rate of replacement of these mortars with pozzolans (15\% by weight). In addition, estratlingite is found in FCC and is not observed in the other mortars, it indicates that only the reactive alumina fraction of FCC has intervened in the pozzolanic reaction.

Thermogravimetric analysis technique allows us to identify and quantify the different hydrates present in the cementing matrix. The thermograms of the mortars were analyzed at 7, 14 and 148 days. It has been estimated portlandite content with weight loss of water in the range 450-550 ० C (Table 3), and differences were observed between the different mortars, mainly attributed to the decomposition reaction [4]:

$$
\mathrm{Ca}(\mathrm{OH})_{2} \rightarrow \mathrm{CaO}+\mathrm{H}_{2} \mathrm{O}
$$

Se observa que el contenido en portlandita de los morteros con puzolana crece desde 7 a 14 días, y decrece ligeramente de 14 a 148 días. Este incremento en la segunda semana no implica que no exista reacción puzolánica, sino que la hidratación del cemento a esas edades es muy importante y la cantidad neta de portlandita aumenta. Por tanto, la cantidad de portlandita fijada (cal fijada) debe ser calculada teniendo en cuenta la proporción de cemento presente en la mezcla cementante (34).

Los valores de fijación de $\mathrm{Ca}(\mathrm{OH})_{2}$ figuran en la Tabla 3. La cantidad de cal fijada de MK es más importante que de FCC, tanto a edad temprana (7 ó 14 días), como a edad tardía (148 días). En el mortero MK, la puzolana ha fijado la mayor parte de la cal antes del día 7 (alrededor del $31 \%$ ), en el intervalo de 7 a 14 días fija hasta el $40 \%$ y en el periodo de 14 a 148 días solamente hasta el $47 \%$. En el mortero FCC se observa una fijación muy importante entre los días 7 a 14 y continúa su fijación de 14 a 148 días. En cualquier caso, los niveles de fijación de cal son importantes en ambos materiales, mostrando la elevada reactividad de ambas puzolanas. El elevado valor de cal fijada en MK hasta día 7 se corresponde con una elevada velocidad de $\rho(\mathrm{d} \rho / \mathrm{dt})$ y con el máximo valor del parámetro $\mathrm{D}$ relativo al poro bloqueado. De 7 a 14 días la cal fijada continúa aumentando y la velocidad de $\rho$ alcanza un máximo, aunque el parámetro $D$ comienza a disminuir.
It is noted that portlandite content of the mortars with pozzolans grows from 7 to 14 days, and decreases slightly from 14 to 148 days. This increase in the second week does not mean that there is no pozzolanic reaction, as it should be noted that the hydration of cement at this age is very important and therefore increases the net quantity of portlandite. Therefore, the amount of portlandite fixed (fixed lime) should be calculated taking into account the proportion of cement in the mixture binder (34).

Values of fixed $\mathrm{Ca}(\mathrm{OH})_{2}$ are shown in Table 3. The amount of lime set of $\mathrm{MK}$ is more important than the FCC, both at an early age (7 or 14 days), as a late age (148 days). In the mortar with $M K$, the pozzolan has fixed most of the lime before day 7 (about 31\%) in the range of 7 to 14 days to $40 \%$ and the period of 14 to 148 days only until $47 \%$. The FCC mortar shows a very important setting from 7 to 14 and continues its fixation from 14 to 148. In any case, fixing levels of lime are important in both materials, showing the high reactivity of both pozzolans. The high value of fixed lime in MK until day 7 corresponds to a high speed of $\rho(d \rho / d t)$ and the maximum value of the parameter $D$ on the blocked pore. From 7 to 14 days fixed lime continues to increase and speed of $\rho$ reaches a maximum, but the parameter $D$ begins to decrease. 
Tabla 3 / Table 3

Datos del análisis termogravimétrico de morteros y evaluación de la portlandita fijada por reacción puzolánica.

(Leyenda: $\mathrm{CH}$ portlandita; $\mathrm{P}_{\mathrm{H}}$ agua combinada en el resto de hidratos).

Thermogravimetric analysis data for mortars and determination of portlandite fixed by means of pozzolanic reaction. (Legend: $\mathrm{CH}$ portlandite; $P_{H}$ combined water for other hydrates).

\begin{tabular}{|c|c|c|c|c|}
\hline \multirow{2}{*}{ Mortero / Mortar } & \multirow{2}{*}{$\begin{array}{l}\text { Tiempo / Time } \\
\text { (día / day) }\end{array}$} & \multicolumn{2}{|c|}{ Productos de hidratación / Hydrated products (\%) } & \multirow{2}{*}{ Cal fijada / Fixed lime (\%) } \\
\hline & & $\mathrm{CH}$ & $\mathbf{P}_{\mathrm{H}}$ & \\
\hline CONTROL & \multirow{3}{*}{7} & 2.14 & 4.50 & 0.00 \\
\hline FCC $15 \%$ & & 1.66 & 4.56 & 8.67 \\
\hline MK $15 \%$ & & 1.26 & 4.97 & 30.63 \\
\hline CONTROL & \multirow{3}{*}{14} & 3.02 & 4.32 & 0.00 \\
\hline FCC $15 \%$ & & 1.98 & 5.05 & 22.85 \\
\hline MK $15 \%$ & & 1.53 & 4.98 & 40.43 \\
\hline CONTROL & \multirow{3}{*}{148} & 2.93 & 4.85 & 0.00 \\
\hline FCC $15 \%$ & & 1.33 & 4.91 & 40.81 \\
\hline MK $15 \%$ & & 1.47 & 5.94 & 46.53 \\
\hline
\end{tabular}

La cal fijada en el FCC evoluciona de forma diferente. A día 7 la fijación es baja. La mayor fijación se produce entre 7 y 14 días, dato que no se refleja en una gran velocidad de $\rho$, pero que se relaciona con el aumento del parámetro $D$. Podemos decir que los productos hidratados provocan diferentes efectos microestructurales en las dos puzolanas: la puzolana MK reacciona una semana antes que el FCC, provocando una superior velocidad de $\rho$ en todo el periodo de hidratación. El valor de $D$ está directamente relacionado con la máxima fijación de cal en ambas puzolanas.

Este análisis termogravimétrico nos permite analizar el resultado de la reacción puzolánica identificando más cantidad y más variedad de producto hidratado. Los valores de agua combinada en el resto de hidratos $\mathrm{PH}$ figuran en la Tabla 3. Se han calculado a partir de la pérdida total de peso en la curva termogravimétrica, restando el agua asociada al hidróxido cálcico (35). El $\mathrm{P}_{\mathrm{H}}$ de morteros con puzolana es igual o mayor que el valor de mortero CONTROL a todas las edades, lo que sugiere que existe una contribución importante en la cantidad de los diferentes hidratos por reacción puzolánica. En la Figura 6 se muestran las curvas termogravimétricas derivadas (DTG) para
The fixed lime in FCC evolves differently. At day 7, the setting is low. The highest fixing is between 7 and 14 days, which is not reflected in a high speed of $\rho$, but it is related to the increase of the parameter $D$. We can say that the hydrated products cause different microstructural effects in the two pozzolans: the MK pozzolan reacts a week before the FCC, resulting in a higher rate of $\rho$ over the whole period of hydration. The value of $D$ is directly related to the maximum setting of lime in both pozzolans.

This thermogravimetric analysis allows us to analyze the result of the pozzolanic reaction identifying more quantity and more variety of hydrated product. The values of combined water in the rest of hydrates $P_{H}$, are listed in Table 3. They are calculated from the total weight loss in the thermogravimetric curve by subtracting the water associated with calcium hydroxide (35). The $P_{H}$ of pozzolanic mortars is equal or greater than the value of CONTROL mortar at all ages, suggesting that there is a significant contribution in the amount of different hydrates by pozzolanic reaction. Figure 6 shows the derivative thermogravimetric curve

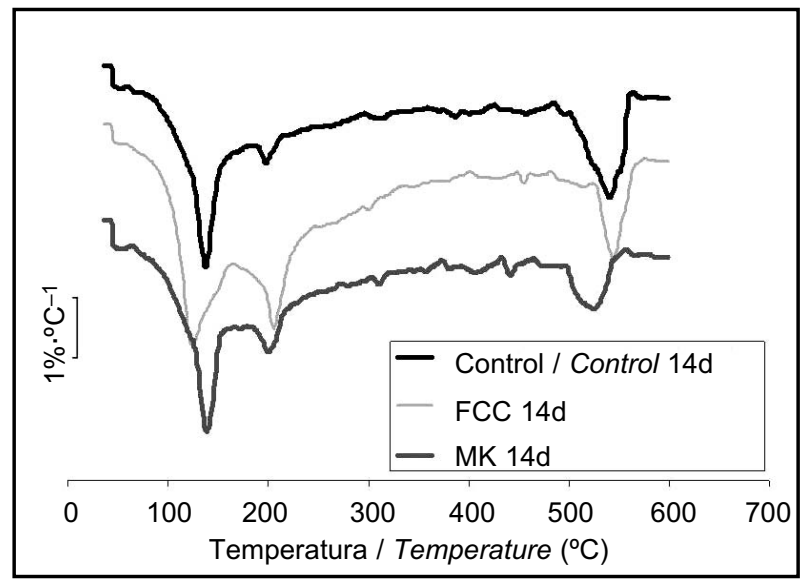

Figura 6. Curvas termogravimétricas derivadas (DTG) para los morteros curados 14 días.

Figure 6. Differential thermogravimetric curves (DTG) for 14-day curing mortars. 
los morteros curados 14 días. Podemos observar claramente un pico situado alrededor de $220^{\circ} \mathrm{C}$, que corresponde a la descomposición de silicoaluminatos cálcicos hidratados CSAH, tipo estratlingita, que son típicos de la reacción de estas puzolanas (34). También se observa que el mortero con FCC presenta un pico más importante para este tipo de hidratos. Se ha descrito (33) que parte de estos productos son de naturaleza cristalina, lo que podría explicar su menor contribución al refinamiento de la estructura porosa que se observa en la resistencia eléctrica.

La evolución con el tiempo de la resistencia mecánica $R_{c}$ a compresión para los distintos morteros se muestra en la Figura 7. También figuran en el mismo gráfico los valores de $R_{c}$ de CONTROL multiplicado por 0,85 con el objeto de comparar la resistencia de los morteros puzolánicos con un control que tenga la misma cantidad de cemento. La resistencia a compresión aumenta con el tiempo de curado para todos los morteros. Los morteros con puzolana tienen valores medios similares o ligeramente superiores a CONTROL, para todas las edades. A partir de los 3 días de curado, los morteros puzolánicos superan al CONTROL en resistencia, en especial el MK. Si comparamos con el valor del $85 \%$ de $\mathrm{R}_{\mathrm{c}}$ para CONTROL, las diferencias a partir de los 3 días de curado son altas y se incrementan progresivamente hasta los 148 días.

Este comportamiento mecánico confirma en cierto grado la fijación de cal debida a las puzolanas. En los primeros días de curado el MK fija mayores porcentajes de cal
(DTG) for 14 days cured mortars. We can clearly observe a peak located around $220^{\circ} \mathrm{C}$, which corresponds to the decomposition of hydrated calcium aluminum silicates CSAH, type estratlingite, which are typical of the reaction of these pozzolans (34). It is also noted that the FCC mortar presents a major peak for these type of hydrates. It has been described (33) that some of these products are crystalline in nature, which could explain their lower contribution to the refinement of the pore structure.

The evolution over time of the compressive strength $R_{C}$ for the different mortars is shown in Figure 7. Also we include in the same graph the $R_{C}$ values of the CONTROL multiplied by 0.85 , in order to compare the resistance of pozzolanic mortars with a control that has the same amount of cement. The compressive strength increases with curing time for all mortars. The pozzolan mortars have values similar or slightly higher than CONTROL, for all ages. After 3 days of curing, pozzolanic mortars overcome to CONTROL in strength, especially $M K$. Comparing with the value of $85 \%$ of $R_{C}$ for CONTROL, differences from 3 days of curing are high and increase progressively up to 148 days.

This mechanical behaviour reflects to some extent the lime fixation due to the pozzolans. In the early days of curing MK fix higher percentages of lime due to smaller

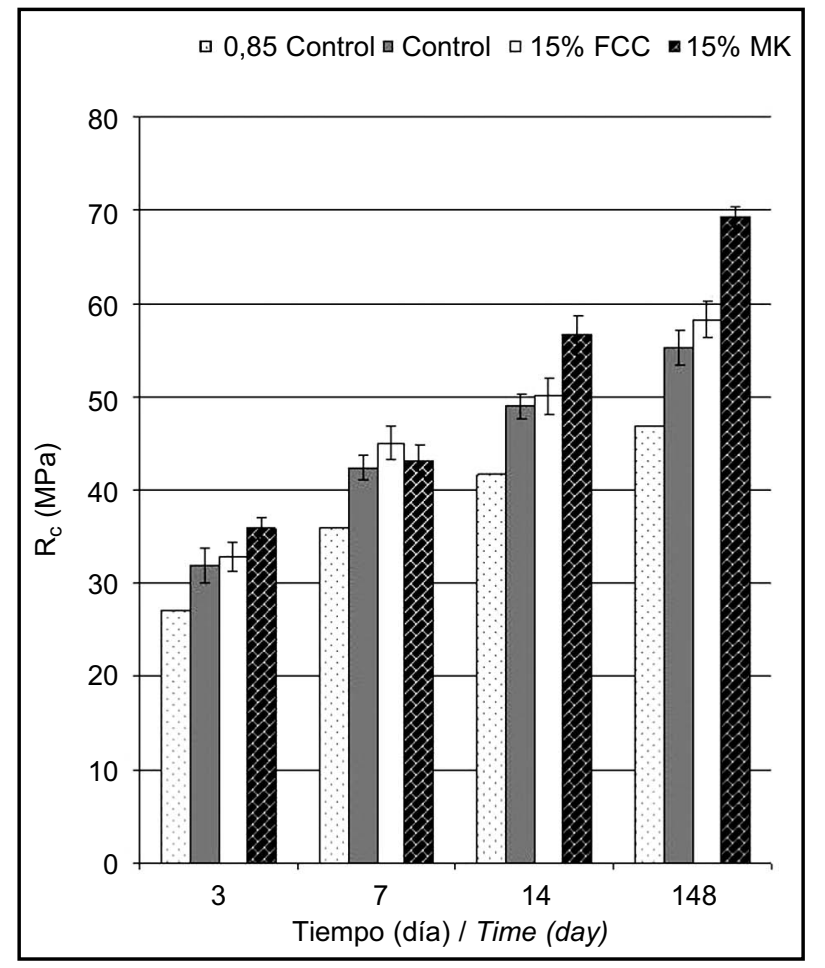

Figura 7. Evolución de la resistencia a compresión de los distintos morteros. Figure 7. Development of compressive strength for different mortars. 
debido al menor tamaño de la partícula y a su mayor superficie específica, propiedades que provocan la aparición de más productos hidratados y la densificación de la matriz.

Con el fin de correlacionar las propiedades eléctricas y la actividad puzolánica la Figura 8 representa la cantidad consumida de cal y la resistividad eléctrica, frente al tiempo de hidratación. Observamos la misma relación cualitativa entre la reacción puzolánica (fijación de cal) y la variación de la resistividad eléctrica del mortero para MK y FCC. Los incrementos de resistividad en ambas puzolanas están asociados a la formación de gran cantidad de productos de hidratación que rellenan el espacio poroso. Sin embargo, a día 148 entre FCC y MK hay una pequeña diferencia en la cal fijada (15\%) y una gran diferencia en la resistividad eléctrica (230\%). La actividad puzolánica de MK produce morteros con gran resistividad y baja porosidad conectada, a largo plazo, mientras que el FCC produce una matriz menos resistiva y por tanto más porosa. La microestructura desarrollada con ambas puzolanas es muy diferente y parece que el desfase en el inicio de la actividad puzolánica podría ser indicativo de estas diferencias. Por tanto, el seguimiento de las medidas eléctricas en los primeros 15 días de hidratación, exponente capacitivo $\alpha$ y velocidad de $\rho$, ha servido para predecir diferencias microestructurales a largo plazo entre morteros con sustituciones del 15\% de FCC y MK. Para generalizar esta observación habría que comprobarla en morteros con puzolanas de distintos porcentaje de sustitución, composición y tamaño. size of particle and its higher specific surface, properties which cause the emergence of more hydrated products and the densification of the matrix.

In order to correlate the electrical properties and pozzolanic activity Figure 8 represents the amount of consumption of lime and electrical resistivity compared with hydration time. We see the same qualitative relationship between the pozzolanic reaction (fixation of lime) and the variation of the electrical resistivity of mortar for MK and FCC. The increase of resistivity in both pozzolans are associated with the formation of large amount of hydration products that fill the pore space. However, there is a small difference in the fixed lime (15\%) and a difference in electrical resistivity (230\%) between FCC and MK at day 148. The pozzolanic activity of MK mortars produce high resistivity and low porosity connected, in the long term, while the FCC produces a less resistive matrix and therefore more porous. The microstructure developed with both pozzolans is very different and it seems that the lag in the onset of the pozzolanic activity could be indicative of these differences. Therefore, monitoring the electrical measurements in the first 15 days of hydration, capacitance exponent $\alpha$ and speed of $\rho$, has been used to predict long-term microstructural differences between mortars with substitutions of $15 \%$ of FCC and MK. To generalize this observation should be checked in mortars with pozzolans from different replacement rate, composition and size.

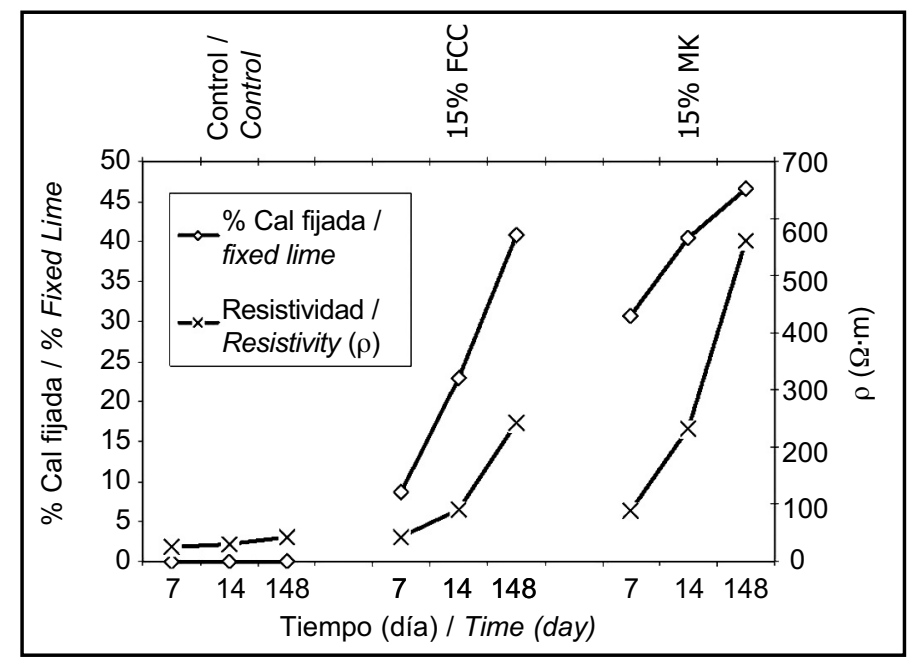

Figura 8. Relación entre la evolución de la fijación de cal y la resistividad de la matriz cementante con el tiempo de curado.

Figure 8. Relationship between fixed lime and resistivity of the cement matrix with curing time.

\section{CONCLUSIONES}

La técnica propuesta de medida de propiedades eléctricas nos permite evaluar parámetros eléctricos (resistividad y factores capacitivos) con incertidumbres aceptables, inferiores al 7\%.

\section{CONCLUSIONS}

The proposed technique for measuring electrical properties allows us to evaluate electrical parameters (resistivity and capacitance factors) with acceptable uncertainty, less than $7 \%$. 
La resistividad de los morteros estudiados tienen valores similares el primer día de curado, a partir de entonces la resistividad aumenta en el siguiente orden: CONTROL $<$ FCC $<M K$. La relación de la resistividad vs CONTROL es: 5,8 para FCC y 13,4 para MK, en el día 148. Estas relaciones reflejan las diferencias en la porosidad conectada derivada de la diferente actividad puzolánica entre FCC y MK.

El exponente capacitivo $\alpha$ nos permite calcular el parámetro fractal $D$ que representa la varianza de tamaño de los poros bloqueados, la cual aumenta con la hidratación. Para los tres morteros este parámetro aumenta en el periodo de hidratación hasta un valor común de alrededor de 2,5. La evolución de este parámetro indica que la actividad puzolánica de MK se adelanta una semana respecto de FCC.

La puzolana MK tiene una elevada reactividad a edad temprana, detectada mediante mediciones de: fijación de cal, exponente capacitivo, velocidad de la resistividad y resistencia mecánica a compresión. La actividad puzolánica de FCC se retrasa con respecto a MK y es menos efectiva.

El aumento de la resistencia mecánica no es proporcional al aumento de la resistividad de la porosidad conectada. Tampoco está relacionada con los parámetros capacitivos relativos a la porosidad bloqueada. Sin embargo, sí se ha observado una correlación directa entre incremento de resistividad y el aumento de la fijación de cal.

La medida no-destructiva de la impedancia eléctrica en las dos primeras semanas de hidratación permite predecir el diferente efecto microestructural que producen las puzolanas en morteros de cemento Portland con hidratación muy desarrollada.

\section{AGRADECIMIENTOS}

Los autores quieren agradecer al Ministerio de Educación y Ciencia (Plan nacional de $I+D+i$ ) por la financiación de los proyectos BIA 2006-15188-C03-02 y BIA 200400520, y la cofinanciación FEDER. También a la Universidad Politécnica de Valencia (Vicerrectorado de Investigación) por la financiación de la beca FPI a L.F. Lalinde (PPI-01-04 ref 5939) y a la financiación del proyecto PAID-05-09 ref 4302.
The resistivity of the studied mortars have similar values on the first day of curing, thereafter the resistivity increases in the following order: Control $<F C C<M K$. The relationship of resistivity vs CONTROL is: 5.8 for FCC and 13.4 to $M K$ on day 148 . These ratios reflect the differences in the connected porosity derived from the different pozzolanic activity between FCC and MK.

The capacitive exponent $\alpha$ allows us to calculate the fractal parameter $D$ that represents the variance in size of the blocked pores, which increases with hydration. For the three mortars this parameter increases in the hydration period to a common value of about 2.5. The evolution of this parameter indicates that the pozzolanic activity of MK is ahead one week to FCC.

The MK pozzolan has a high reactivity at an early age, detected by measurements of: fixing cal, exponent capacitive speed of resistivity and mechanical resistance to compression. The FCC pozzolanic activity lags behind $M K$ and is less effective.

The increase in mechanical strength is not proportional to the increase in resistivity of the connected porosity. Neither is related to the capacitance parameters on the porosity blocked. However, it has seen a direct correlation between increase in resistivity and increase in lime fixed.

The non-destructive measurement of electrical impedance in the first two weeks of hydration can predict the different microstructural effect produced by pozzolans in Portland cement mortars with very advanced hydration.

\section{ACKNOWLEDGMENTS}

Authors thank to Ministerio de Educación (Spanish research plan) the financial support to the projects BIA 2006-15188-C03-02 y BIA 2004-00520, with FEDER cofinancing. Also thank to Universidad Politécnica de Valencia (Vicerrectorado de Investigación) the research grant for L.F. Lalinde (PPI-01-04 ref 5939) and financial support to the project PAID-05-09 ref 4302.

\section{BIBLIOGRAFÍA / BIBLIOGRAPHY}

(1) Snyder, K. A.; Bentz, D. P.: "Suspended hydration and loss of freezable water in cement pastes exposed to $90 \%$ relative humidity". Cem. Concr. Res., vol. 34, no 11 (2004), pp. 2045-2056. doi:10.1016/j.cemconres.2004.03.007

(2) Cabeza, M.; Keddam, M.; Novoa, X. R.; Sanchez, I.; Takenouti, H.: "Impedance spectroscopy to characterize the pore structure during the hardening process of Portland cement paste". Electrochim. Acta, vol. 51, no 8-9 (2006), pp. 1831-1841. doi:10.1016/j.electacta.2005.02.125 
(3) Snyder, K. A.: "The relationship between the formation factor and the diffusion coefficient of porous materials saturated with concentrated electrolytes: theoretical and experimental considerations". Concr. Sci. Eng., vol. 3, no 12 (2001), pp. 216-224.

(4) Alonso, C.; Andrade, C.; Izquierdo, M.; Novoa, X. R.; Perez, M. C.: "Effect of protective oxide scales in the macrogalvanic behaviour of concrete reinforcements". Corros. Sci., vol. 40, no 8 (1998), pp. 1379-1389. doi:10.1016/S0010-938X(98)00040-7.

(5) Cabeza, M.; Merino, P.; Miranda, A.; Novoa, X. R.; Sanchez I.: "Impedance spectroscopy study of hardened Portland cement paste". Cem. Concr. Res., vol. 32, no 6 (2002), pp. 881-891. doi:10.1016/S0008-8846(02)00720-2

(6) Ji, X.; Chan, S.Y.N.; Feng, N.: "Fractal model for simulating the space-filling process of cement hydrates and fractal dimensions of pore structure of cement-based materials". Cem. Concr. Res., vol. 27, no 11 (1997), pp. 1691-1699. doi:10.1016/S0008-8846(97)00157-9

(7) Malhotra, V. M.; Mehta, P. K.: Pozzolanic and cementitious materials. Gordon and Brach Publishers, Ottawa, 1996.

(8) De Silva, P. S.; Glasser, F. P.: "Phase relations in the system CaO-Al2O3-SiO2-H2O relevant to metakaolin-calcium hydroxide hydration". Cem. Concr. Res., vol. 23, no 3 (1993), pp. 627-639. doi:10.1016/0008-8846(93)90014-Z

(9) Murat, M.; Comel, C.: "Hydration reaction and hardening of calcined clays and related minerals. Influence of calcination process of Kaolinite on mechanical strengths of hardened metakaolinite". Cem. Concr. Res, vol. 13, no 5 (1983), pp. 631-637. doi:10.1016/00088846(83)90052-2

(10) Payá, J.; Monzó, J.; Borrachero, M. V.: "Physical, chemical and mechanical properties of fluid catalytic cracking catalyst residue (FC3R) blended cements". Cem. Concr. Res., vol. 31, no 1 (2001), pp. 57-61. doi:10.1016/S0008-8846(00)00432-4

(11) Zornoza, E.; Garcés, P.; Payá, J.: "Estudio de la velocidad de corrosión de aceros embebidos en morteros de cemento sustituidos con residuo de catalizador de craqueo catalítico (FC3R)". Mater. Construcc., vol. 58, no 292 (2008), pp. 27-43.

(12) Borrachero, M. V.; Monzó, J.; Payá, J.; Peris-Mora, E.; Vunda, C.; Velázquez, S.; Soriano, L.: "El catalizador gastado de craqueo catalítico adicionado al cemento Portlánd: las primeras 48 horas de curado y la evolución de la resistencia mecánica". VIII Congreso Nacional de Propiedades Mecánicas de Sólidos, Gandia (2002), pp. 579-589.

(13) García de Lomas, M.; Sánchez de Rojas, M.; Frías, M. I.: "Pozzolanic reaction of a spent fluid catalytic cracking catalyst in FCCcement mortars". J. Therm. Anal. Cal., vol. 90, no 2 (2007), pp. 443-447.

doi:10.1007/s10973-006-7921-7

(14) Pinto, C.; Büchler, P. M.; Dweck, J.: "Pozzolanic properties of a residual FCC catalyst during the early stage of cement hydration". J. Therm. Anal. Cal., vol. 87, no 3 (2007), pp. 715-720. doi:10.1007/s10973-006-7772-2

(15) Soriano Martínez, L.: "Nuevas aportaciones en el desarrollo de materiales cementantes con residuo de catalizador de craqueo catalítico usado". Tesis Doctoral, Universidad Politécnica de Valencia, Valencia, 2007.

(16) Payá, J.; Monzó, J.; Borrachero, M. V.; Velázquez, S.: "Chemical activation of pozzolanic reaction of fluid catalytic cracking residue (FC3R) in lime pastes: thermal analysis". Adv. Cem. Res., vol. 16, no 3 (2004), pp. 123-130.

(17) McCarter, W. J.; Starrs, G.; Chrisp, T. M.: "Electrical conductivity, diffusion, and permeability of Portland cement-based mortars". Cem. Concr. Res., vol. 30, no 9 (2000), pp. 1395-1400. doi:10.1016/S0008-8846(00)00281-7

(18) Torrents, J. M.; Mason, T. O., Garboczi, E. J.: "Impedance spectra of fiber-reinforced cement-based composites. A modeling approach". Cem. Concr. Res., vol. 30, no 4 (2000), pp. 585-592. doi:10.1016/S0008-8846(00)00211-8

(19) Kim, Y.-M.; Lee, J.-H.; Hong, S.-H.: "Study of alinite cement hydration by impedance spectroscopy". Cem. Concr. Res., vol. 33, no 3 (2003), pp. 299-304. doi:10.1016/S0008-8846(02)00944-4

(20) McCarter, W. J.; Starrs, G.; Chrisp, T. M.: "The complex impedance response of fly-ash cement revisited". Cem. Concr. Res., vol. 34, no 10 (2004), pp. 1837-1843. doi:10.1016/j.cemconres.2004.01.013

(21) He, Z.; Li, J.: "Non-contact resistivity measurement for characterization on thr hydration process of cement-paste with excess alkali". Adv. Cem. Res., vol. 16, no 1 (2004), pp. 29-34.

(22) Schiefelbein, S. L.; Fried, N. A.; Rhoads, K. G.; Sadoway D. R.: "A high-accuracy, calibration-free technique for measuring the electrical conductivity of liquids". Rev. Sci. Instrum., vol. 69, no 9 (1998), pp. 3308-3313. doi:10.1063/1.1149095

(23) MacDonald, J. R.: "Impedance Spectroscopy", Wiley, New York, 1987.

(24) Yoon, S. S.; Kim, H. C.; Hill, R. M.: "The dielectric response of hydrating porous cement paste". J. Phys. D: Appl. Phys., vol. 29, no 3 (1996), pp. 869-875. doi:10.1088/0022-3727/29/3/054

(25) Wei, X.; Li, Z.: "Study on hydration of Portland cement with fly ash using electrical measurement". Mater. Struct., vol. 38, no 3 (2005), pp. 411-417.

(26) Olson, R. A.; Jennings, H. M.: "Estimation of C-S-H content in a blended cement paste using water adsorption". Cem. Concr. Res., vol. 31, no 3 (2001), pp. 351-356. doi:10.1016/S0008-8846(01)00454-9

(27) Thomas, J. J.; Jennings, H. M.: "Effects of D2O and mixing on the early hydration kinetics of tricalcium silicate". Chem. Mater., vol. 11 , no 7 (1999), pp. 1907-1914. doi:10.1021/cm9900857

(28) Livingston, R. A.: "Fractal nucleation and growth model for the hydration of tricalcium silicate". Cem. Concr. Res., vol. 30, no 12 (2000), pp. 1853-1860. doi:10.1016/S0008-8846(00)00457-9

(29) Heinemann, A.; Hermann, H.; Haussler, F.: "SANS analysis of fractal microstructures in hydrating cement paste". Physica B 276278 (2000), pp. 892-893. doi:10.1016/S0921-4526(99)01279-X

(30) Ficker, T.; Len, A.; Nemec, P.: "Notes on hydrated cement fractals investigated by SANS". J. Phys. D: Appl. Phys., vol. 40, no 13 (2007), pp. 4055-4059. doi:10.1088/0022-3727/40/13/023 
(31) Kriechbaum, M.; Degovics, G.; Tritthart, J.; Laggner, P.: "Fractal structure of Portland cement paste during age hardening analyzed by small-angle-X-ray scattering". Trends in colloid and Interface Science, vol. 79 (1989), pp. 101-105.

(32) Chindaprasirt, P.; Rattanasak, U.; Kendall, K.: International Conference on Pozzolan, Concrete and Geopolymer, Khon Kaen, Thailand, May 24-25 (2006), pp. 262-270.

(33) Payá, J.; Monzó, J.; Borrachero, M. V.; Peris-Mora, E.; Soriano, L.; Velázquez, S.: "Study on the properties of different spent silicoaluminous catalysts and their use in cementing mixtures". Eighth CANMET/ACI International Conference on Flyash, Silica Fume, Slag And Natural Pozzolans in Concrete. Las Vegas, USA. May 23-29 (2004), pp. 513-527.

(34) Payá, J.; Monzó, J.; Borrachero, M. V.; Velázquez, S.: "Evaluation of the pozzolanic activity of fluid catalytic cracking catalyst residue (FC3R): Thermogravimetric analysis studies on FC3R- Portland cement pastes". Cem. Concr. Res., vol. 33, no 4 (2003), pp. 603609. doi:10.1016/S0008-8846(02)01026-8

(35) Payá, J.; Monzó, J.; Borrachero, M. V., Velázquez, S.: "The chemical activation of pozzolanic reaction of fluid catalytic cracking catalyst residue (FC3R) in lime pastes". Adv. Cem. Res., vol. 19, no 1 (2007), pp. 9-16. doi:10.1680/adcr.2007.19.1.9 